\title{
Diversity as an Influence on the Choice of Teaching Positions by Pre-service Students in Special Education
}

Tara A. Brooks

West Virginia University

Follow this and additional works at: https://researchrepository.wvu.edu/etd

\section{Recommended Citation}

Brooks, Tara A., "Diversity as an Influence on the Choice of Teaching Positions by Pre-service Students in Special Education" (2011). Graduate Theses, Dissertations, and Problem Reports. 3060.

https://researchrepository.wvu.edu/etd/3060

This Dissertation is protected by copyright and/or related rights. It has been brought to you by the The Research Repository @ WVU with permission from the rights-holder(s). You are free to use this Dissertation in any way that is permitted by the copyright and related rights legislation that applies to your use. For other uses you must obtain permission from the rights-holder(s) directly, unless additional rights are indicated by a Creative Commons license in the record and/ or on the work itself. This Dissertation has been accepted for inclusion in WVU Graduate Theses, Dissertations, and Problem Reports collection by an authorized administrator of The Research Repository @ WVU.

For more information, please contact researchrepository@mail.wvu.edu. 
Diversity as an Influence on the Choice of Teaching Positions by

Pre-service Students in Special Education

\title{
Tara A. Brooks
}

Dissertation submitted to the

College of Human Resources and Education at

West Virginia University

in partial fulfillment of the requirements

for the degree of

\author{
Doctor of Education \\ in \\ Special Education
}

Barbara L. Ludlow, Ed. D., Chair

Elizabeth A. Dooley, Ed. D.

Katherine J. Mitchem, Ph. D.

Richard T. Walls, Ph.D.

Jacqueline L. Webb-Dempsey, Ph.D.

Department of Special Education

Morgantown, WV

2011

Keywords: student diversity characteristics, teacher preparation programs, special education, initial teaching position 


\section{Abstract \\ Diversity as an Influence on the Choice of Teaching Positions by Pre-service Students in Special Education}

Tara A. Brooks

With today's increasingly diverse classrooms, teachers are challenged to provide strategies that are effective in ensuring that all students reach success, regardless of race, class, or disability. Teacher education programs are also responsible for providing the type of experiences that prepare graduates to meet the needs of today's diverse classrooms. This study investigated the types of hypothetical teaching positions that pre-service students in special education deem as most ideal and the factors present within those positions. It also sought to determine if any relationship existed between participants' perceptions of beliefs and their choices of teaching positions. Pre-service students in special education at West Virginia University were asked to rank six (6) teaching positions from most ideal to least ideal. Follow-up interviews were conducted to ascertain the motives behind the rankings and also to determine what factors specifically influenced the type of teaching positions that are chosen upon graduation.

Preliminary results of this study indicate that participants were more drawn to wealthy suburban areas, with little to no racial diversity. However, additional data revealed that participants had a preference for more diversity in terms of race, class, and disability in their ideal teaching positions yet felt as if they were not prepared to effectively teach in these particular teaching environments. The results also indicated that participants found that they were provided with ample clinical experience, yet more exposure to specific areas of student diversity, namely race, class, and disability is needed within these clinical experiences in order for graduates to feel adequately prepared to teach in today's classrooms. 


\section{Acknowledgements}

There are so many individuals who have walked alongside me on this long journey, but I would thank to first give thanks to God for blessing me with the strength, endurance, and the passion to reach the end of this path. I would particularly like to thank my committee members for sticking with me throughout this process and believing that I had the ability to accomplish this task. Special thanks to my chair, Dr. Barbara Ludlow, for her continued guidance and persistence in helping me to accomplish my goal. Thank you to my mentor, Dr. Dooley, for teaching me and for setting the example of the woman that I aspire to become. Thank you to Dr. Mitchem, Dr. Webb-Dempsey and Dr. Walls for their continued support, words of encouragement, and guidance. A very special thank you to, Dr. Kalie Kossar, who became my colleague and friend and whose support, guidance, leadership, and passion made her a constant in both my personal and professional lives.

I would like to thank my grandmother, Elizabeth Belle Redman, for always believing in me and my abilities. She was there with me through those first couple of years, every day, inspiring and instilling value in me. When she passed away, I thought about quitting but knew that she would continue to support me and see me through. Thank you to my family, particularly my parents, for supporting me through my continued journey towards yet another degree. My siblings, Buck, Linnea, and Bianca, I could not have done this without your love and support. I dedicate this to my six nieces and nephews; I did this for you, to show you the value in education and that you, too, can achieve whatever it is that you set your mind towards. I love you all. 


\section{Table of Contents}

\section{Chapter One}

$\begin{array}{ll}\text { Introduction } & 1\end{array}$

Statement of the Problem 4

Purpose of the Study $\quad 8$

$\begin{array}{ll}\text { Research Questions } & 9\end{array}$

Glossary of Terms 9

$\begin{array}{ll}\text { Summary } & 9\end{array}$

\section{Chapter Two Review of the Literature}

$\begin{array}{ll}\text { Introduction } & 11\end{array}$

$\begin{array}{ll}\text { Defining Diversity } & 11\end{array}$

Student Diversity 12

$\begin{array}{ll}\text { Race } & 13\end{array}$

$\begin{array}{ll}\text { Class } & 14\end{array}$

$\begin{array}{ll}\text { Disability } & 16\end{array}$

$\begin{array}{ll}\text { Intersection of race, class, and disability } & 17\end{array}$

Impact of Student Diversity Characteristics 18

Teacher Education Programs $\quad 24$

Pre-service Student Expectations of the Field 24

$\begin{array}{ll}\text { Program Review } & 27\end{array}$

Factors Affecting Job Choices $\quad 30$

$\begin{array}{ll}\text { Conclusion } & 32\end{array}$ 


\section{Chapter Three Method}

Purpose of Study 34

Research Questions $\quad 34$

$\begin{array}{ll}\text { Participants } & 34\end{array}$

Research Design $\quad 35$

Role of the Researcher 36

Data Collection - Instrumentation 38

Data Collection - Procedures $\quad 40$

Data Analysis 42

Credibility of the Study 45

Summary 46

\section{Chapter Four Results}

$\begin{array}{ll}\text { Results } & 48\end{array}$

Research Question $1 \quad 50$

Position Chosen Most Frequently as Least Ideal 52

Discussion of Other Positions Chosen as Most Ideal 53

Research Question 2

Race, Class, and Disability $\quad 55$

$\begin{array}{ll}\text { Data Analysis Map } & 58\end{array}$

Level $1 \& 2$

Level $3 \& 4$

Descriptions of Ideal Teaching Positions 64 
Level $5 \quad 66$

$\begin{array}{ll}\text { Level } 6 & 70\end{array}$

$\begin{array}{ll}\text { Conclusion } & 71\end{array}$

\section{Chapter Five Discussion}

$\begin{array}{ll}\text { Introduction } & 73\end{array}$

Summary of Purpose 73

Summary of Findings $\quad 74$

$\begin{array}{ll}\text { Discussion } & 78\end{array}$

$\begin{array}{ll}\text { Conclusions } & 79\end{array}$

Implications for Policy and Practice 86

$\begin{array}{ll}\text { Limitations } & 87\end{array}$

Recommendations for Future Research 90

\section{Appendix A}

$\begin{array}{ll}\text { Letter to Participants } & 92\end{array}$

Consent and Information Form 93

Interview Protocol 95

\section{Appendix B}

Why go into Teaching? Participant response table 101 


\section{List of Tables}

4.1 Hypothetical Teaching Positions and Characteristics 48

Present in Each

4.2 Participant Demographics 49

4.3 Summary of Hypothetical Teaching Position Rankings 50

4.4 Comparison of Hypothetical Teaching Positions Chosen as 51

Most and Least Ideal

4.5 Most Important Factor Considered in Ranking Ideal Teaching 55

Positions

4.6 Conceptual Categories and Open Codes 60

4.7 Data Comparison of Three (3) Partiicipants from Same City 70

\section{List of Figures}

3.1 Data Analysis Map 43

4.1 Data Analysis Map (Results) 61 


\section{Chapter One}

\section{Introduction}

An historical look at special education reveals a progression from a law originally passed to mandate that states and localities provide access to public education to students with disabilities to one that requires these individuals to be provided programs and services to achieve equitable educational outcomes based on national standards. The Education for All Handicapped Children Act (Public Law 94-142) was enacted by Congress in 1975 as a means of protecting the rights and meeting the needs of individuals with disabilities (Office of Special Education Programs, 2009). The formation of special education law was laid during a time when the United States Supreme Court ruled "separate but equal" education to be unconstitutional (Keogh, 2007). In response to changing needs over the years, several re-authorizations were enacted for this law, now known as the Individuals with Disabilities Education Act (IDEA). IDEA 2004 incorporated mandates of The No Child Left Behind Act to ensure that students with disabilities receive appropriate services by highly qualified teachers to achieve proficiency in academic content areas. The problem lies in the interpretation by specific states of the definition of highly qualified as well as how some teachers actually become "qualified". Much attention has been paid to these issues, especially as the composition of classrooms today includes more students identified not only with disabilities but those representing many other populations defined as diverse.

The statistics pertaining to the diversity of today's classrooms outline how quickly our nation has changed. The National Center for Education Statistics report on "The Condition of Education" (2009) shows that the percentage of racial/ethnic minority students enrolled in the nation's public schools increased from $22 \%$ in 1972 to $31 \%$ in 
1986 to $43 \%$ in 2006. Brown (2007) states that this "dramatic demographic shift in the United States is more apparent in the public schools than anywhere else." (p. 57). Although these discussions surrounding this increasing diversity have taken place for the past few decades, it is still uncertain as to whether or not ALL students are provided with an equal education. There is additional concern about the overrepresentation of students from minority and impoverished backgrounds in special education classes (Borgemenke, 2001).

A focus for researchers in the past, present, and future is an examination of how well pre-service and first-year teachers are prepared to address the numerous differences that are found in an average classroom. With the demographic composition of today's classrooms changing on a daily basis, teacher education programs are charged with preparing pre-service students to meet those changing needs. Many researchers reference this fact as they examine the shortages in the current teaching force in an effort to redesign teacher education program curriculum and teaching strategies employed in today's classrooms (Barnes, 2006; Boyd, 1996; Cannella \& Reiff, 1994; Holm \& Horn, 2003; Melnick \& Zeichner, 1998; Milner, Flowers, L.A., Moore, Jr, E., Moore, III, J.L., Flowers, T.A., 2003; Pohan, 1996; Rao, 2005; SaponShevin \& Zollers, 1999; Swartz, 2003; Wallace, 2001; Weisman \& Garza, 2002). Therefore, graduates must be prepared with the skills necessary to educate ALL students regardless of race, class, culture, or any other factor that makes them "different" from the majority of their peers. There are some researchers who feel that the mere way in which a teacher interacts with a child can "... affect the self-esteem and 
academic success of students from these varied racial, cultural, and linguistic backgrounds" (Brown, 2007, p. 57).

An acceptance of student diversity characteristics by every teacher is necessary in order for students from all backgrounds to succeed in today's classrooms. In her article about a report issued by Public Agenda, Wasley (2008) discussed a survey of 641 first-year teachers that found that an overwhelming majority of respondents (76\%) felt that they were not prepared to teach students from racially and ethnically diverse backgrounds. Study findings found that these teachers felt not only ill-prepared to teach students from diverse backgrounds but also those with special needs. With educators who are uncomfortable with, or who don't fully understand the appropriate strategies for teaching in diverse classroom environments, students will undoubtedly not be able to reach their full academic potential. Therefore, teacher education programs are now being charged with producing graduates who have encountered a variety of learning experiences, both in the instructional classroom and clinical placements.

Teacher education programs are designed to provide pre-service students with rigorous curriculum and adequate field experiences that help prepare them for future jobs. Given that many of today's schools have changed from being predominantly White and have even been projected to undergo an larger statistical change in the coming years towards a population where the majority is composed of students with various types of diversity characteristics, pre-service students should be trained in the use of research based strategies that provide opportunities for students from these diverse backgrounds as well as those with special needs to fully access the curriculum. In their teacher education courses, prospective teachers learn about students from 
diverse backgrounds, but are they trained to fully understand and meet the needs of this population? What type of training would facilitate this? Without adequate training, how can teachers relate to students who are "different"? Brown (2007) referenced Gary Howard's We Can't Teach What We Don't Know in her attempt to answer this question. She says that the statement applies not only to content but also to the student population. She continues "...too many teachers are inadequately prepared..." to understand the needs of students from various cultural and ethnic backgrounds (p. 58). Preparation may also affect the type of teaching positions new teachers seek. When looking for their ideal teaching position, do graduates of teacher education programs consider how diverse the school population may or may not be? Does this consideration determine whether or not they accept the position? Answers to these questions are crucial to the future of the special education field. Since a nationwide shortage of special education teachers exists, further inquiry into these issues is necessary. In order to provide teacher education programs with the tools necessary to adequately address these issues, research must be done to determine not only the types of positions chosen most frequently but also the characteristics present within them, specifically diversity characteristics.

\section{Statement of the Problem}

Since the composition of the average classroom today has changed a considerable amount as compared with that from the past, teachers are faced with teaching a more diverse population of students than ever before. According to the U.S. Department of Education's National Center for Education Statistics (2008), there were over 49 million students enrolled in public schools in 2006. Of this population, $13.8 \%$ 
received special education services and $38.3 \%$ were eligible for free and reduced lunches. The racial breakdown was as follows: $57.1 \%$ White, non-Hispanic; $19.8 \%$ Hispanic; 17.2\% Black, non-Hispanic; 4.6\% Asian/Pacific Islander; and 1.2\% American Indian/Alaska Native (US Department of Education, 2008). These figures support the notion of increased levels of diversity in classrooms across the nation. The range of differences includes students from various cultural backgrounds, such as race, ethnicity, religion, and socio-economic status as well as those with different learning styles and identified disabilities. Many schools and districts have gone to full inclusion models, where students with mild to moderate disabilities are educated in the general education classroom with all or part of the responsibility for individualized instruction falling on the general education teacher. The situation described indicates that today's classroom teachers should be able to provide the most effective instruction designed to meet each and every student's needs. This also indicates that pre-service students should enter the teaching field with open minds, high expectations, and the ability to create a learning environment that is conducive to learning for all (Swartz, 2003).

Since teaching is the profession that shapes the future of our nation, DarlingHammond (1999) emphasized a need for a more "well-prepared, diverse, and culturally sensitive teacher workforce..." (p.275). Teachers in today's classrooms are faced with issues of student diversity and require a new set of skills in order to ensure that they provide an environment where all students are able to meet with success. Villegas and Lucas (2002) identified six characteristics of a culturally responsive teacher. They argue that teacher education programs "...must first articulate a vision of teaching and learning in a diverse society" and incorporate these strands into their curriculum in order 
to fully prepare pre-service students as culturally responsive (p. 30). Both Gay (2000) and Ladson-Billings (1995) specifically identify several dimensions of culturally responsive teaching, such as academic achievement, cultural competence, and sociopolitical critique. Teacher education programs that lack the ability to provide curriculum allowing pre-service teachers with ample exposure to students from diverse populations in regards to race, class, and disability, often fail to produce culturally responsive teachers. These pre-service teachers require not just appropriate instruction and strategies, but also opportunities to turn research into practice. The more opportunities for practice that they experience, the more likely they will be to become culturally responsive. Swartz (2003) posited that if pre-service students fail to develop dispositions toward diverse student populations, they will continue to hold on to "longheld assumptions" and will not "...consider new knowledge and examine ways to change conventions." (p. 263).

Very few studies have examined the relationship between pre-service students' attitudes and beliefs toward students from different racial and ethnic backgrounds, those who are poor, and most importantly those with special needs and the effect of those beliefs on teaching strategies implemented in the classroom. More information is needed for determination of the types of attitudes held by these students that affect their teaching practices and thus, the types of teaching environments that they feel most effective in. An inquiry into the types of positions chosen and the factors affecting those choices was needed. With such high turnover in the field of special education, an examination of pre-service students was needed to determine if a relationship exists between their perceived competence related to this diversity and their choice of 
hypothetical teaching position. Knowing this information will help teacher education programs better prepare their graduates, especially with providing them with opportunities for diverse field experiences.

The type of field experience that pre-service students receive often is based upon the availability of cooperating teachers or a district's proximity to the main campus. Because of this, characteristics of the placements for students vary based upon school size, average socio-economic status of the community, racial make-up of students, and number of students with disabilities and the manner in which they are served. The amount of and type of exposure to student diversity characteristics experienced by each pre-service student can differ greatly. At a Research University Classification (High Research Activity) institution, the Five-Year Teacher Education Program is designed so that pre-service students are prepared in both theory and in practice to become effective educators. In their article, Larkin and Sleeter (1995) identify three important dimensions of teacher preparation: knowledge base, pedagogical practices, and personal attributes. The curriculum at this institution is definitely aligned with the first two dimensions discussed; however, it is not certain whether close examination into the character traits, values, and attitudes of pre-service students exist. Personal attributes are gained during childhood and often it is hard to unlearn specific thought processes. It may be that one can never truly prepare a pre-service student in this dimension, yet someone wishing to teach in today's classrooms will need to possess specific understandings of the characteristics of student diversity that will allow them to be open and accepting of the differences that they will encounter. More in-depth studies are 
needed to focus on areas of student diversity (race, class, and disability) and how it is incorporated into each of the identified dimensions during preparation phases.

\section{Purpose of Study}

An inquiry based upon the problems outlined above attempted to ascertain what types of teaching positions pre-service students regard as most ideal and the characteristics of student diversity present within those selections. Secondly, the factors they considered and reported as having affected their choices. An attempt was made to determine how data obtained from these inquiries affected the types of job choices that they would make upon graduation and why. Thus, the purpose of this study was to use a phenomenological approach to understand the specific characteristics of student diversity that pre-service students looked for or avoided as they ranked hypothetical teaching positions from most to least ideal. The examination attempted to determine the characteristics of student diversity present or absent in a hypothetical teaching position for pre-service students to deem it as ideal. Student diversity is defined as individual differences in race, class, and disability. This study was developed to explore whether a relationship exists between pre-service students' perceptions of the diversity characteristics mentioned above and their choices of a hypothetical teaching position. Other variables will be embedded within the positions to further delineate the factors that affect these choices.

This study was designed to highlight any and all perceptions that may be held by pre-service students. It sought to delve into the specific attitudes and beliefs about specific characteristics of student diversity and how those perceptions may have affected their choices as they ranked hypothetical teaching positions. The researcher 
wanted to find out if this population of pre-service students enrolled in a teacher education program would select (or avoid) hypothetical teaching positions based upon the presence or absence of diversity related to race, class, and disability. In order to gain this information, it was necessary to present the study in a manner in which the participants would physically rank positions and then would be asked follow-up questions regarding those rankings.

\section{Research Questions}

RQ1: What types of hypothetical teaching positions do pre-service students in special education choose based upon the presence or absence of specific characteristics associated with student diversity, namely race, class, or disability?

RQ2: What factors do pre-service students in special education report as influencing their choices when selecting an ideal hypothetical teaching position?

Glossary of Terms (Merriam-Webster, 1998)

1. Diversity - the condition of being different from one another .

2. Race - a division of mankind possessing traits that are transmissible by descent and sufficient to characterize it as a distinct human type.

3. Class - a group who shares the same economic or social status.

4. Disability - the condition of being physically or mentally impaired.

5. Pre-service student - those students enrolled in a teacher education program who are not yet employed in professional teaching positions.

\section{Summary}

In this chapter, a discussion of the changing demographics of classrooms of today was presented. A need to examine pre-service students' job choices was then 
outlined and the study introduced. Because graduates of the Five-Year Teacher Education Program at the institution where the study took place have chosen employment all over the nation in various different arenas, an examination into factors that may have affected these choices was needed. The researcher hoped to identify a possible need for more exposure to areas of diversity such as race, class, disability, and the intersection of the three. Determining the factors that pre-service students consider when selecting hypothetical teaching positions can offer some insight into perceptions of characteristics of student diversity held by these pre-service students. 


\section{Chapter Two}

\section{Review of the Literature}

\section{Introduction}

The purpose of this chapter was to review the literature on the increasingly diverse society, how it relates to race, class, disabilities and the intersection of the three and what implications there are for the preparation of teachers. An examination into other areas such as teacher shortages, beginning teachers' voices, teacher education programs, and factors associated with career choice is also included in an effort to highlight a need for more research on pre-service students and their post-graduation job plans.

\section{Defining Diversity}

An Internet search for a definition of the term diversity produced results that ranged from variety to heterogeneity to difference to "Understanding and valuing the range and variety of characteristics and beliefs of individuals (including those who provide services to exceptional children, youth and adults) who demonstrate a wide range of characteristics. This includes ethnic and racial backgrounds, language, age, abilities, family status, gender, sexual orientation, socioeconomic status, religious and spiritual values, geographic location, and country of origin" (Council for Exceptional Children, 2008). The latter seemed more fitting for this review and thus should be kept in mind as the term is used throughout. Diversity has recently become a "hot topic" found in all components of life. In fact, scholars in such fields as special education, multicultural education, race relations, social work, and journalism have addressed diversity issues for years. Recent educational research in this area has attempted to show the intersection between the diverse areas of race, class, and disability. 


\section{Student Diversity}

In the search for literature on student diversity, a large number of authors were found to begin their articles with just how increasingly diverse society has become and how the population of students from various backgrounds has grown exponentially, shifting the demographics of today's classrooms (Boyd, 1996; Cannella \& Reiff, 1994; Holm \& Horn, 2003; Pohan, 1996; Rao, 2005; Sapon-Shevin \& Zollers, 1999; Tyler \& Smith-Davis, 2000; Wallace, 2001; Weisman \& Garza, 2002). No longer do they contain homogenous groups of children; instead, they are reflective of the ever changing society and comprise a more diverse student population. Even within special education classrooms, "special educators are working with more racially and ethnically diverse student populations who possess a wide range of abilities in their classrooms" (Green, 2007, p.12).

What Brown (2007) identified as the problem is not related to the changing demographics but to the way in which educators respond to that change. The inability of educators to adjust their perceptions, stereotypes, and beliefs about students from differing racial, cultural, and linguistic backgrounds has led to an increase in the number of students from diverse backgrounds placed into special education programs. These discussions have been taking place for decades about the high numbers of students from diverse backgrounds being placed in special education programs. According to Kea and Utley (1998), these students are "unrecognized, misunderstood, or devalued" (p. 44). When educators hold low expectations and negative perceptions of students, performance levels fall well below actual potential. In fact, Coutinho and Oswald (2004) go so far as to state that "the overrepresentation of culturally and linguistically diverse 
children in special education and the quality of their educational experiences have been regarded as among the most significant issues faced by the U.S. public schools system in the past 30 years"(p. 3). Behaviors can also erupt as a result of this inadequate instruction. Wrongfully identified students are then segregated in special education classrooms. Therefore, in order to effectively meet the needs of students from diverse populations, pre-service students must assess culture, value diversity, manage the dynamics of difference, adapt to diversity, and institutionalize cultural knowledge (Robins et al., 2006).

\section{Race.}

Racial inequalities are common in the education system. Parrish (2002) [as cited in Skiba, Simmons, Ritter, Gibb, Rausch, Cuadrado, and Chung, 2008, p. 269] found that African American students were the most overrepresented group in special education in nearly every state in the nation. Other researchers have studied the overrepresentation of African Americans, especially males, in special education (Artiles, Rueda, Salazar, \& Higareda, 2005; Edwards, 2004; Valenzuela, Copeland, Qi, \& Park, 2006). The effects of these racial inequalities in the classroom between the majority (White) and the minority (African American, Hispanic, for example) populations of students have raised great concern about achievement gaps. Referring to a recent National Center for Education Statistics report, Chism (2009) states "In 2007, national performance averages indicated a 27-point gap between Caucasian and AfricanAmerican fourth-grade reading scores and a 26- point gap between Hispanic and Caucasian students" (p.1). These significant differences impact not only the school 
achievement of low-performing students, but also their opportunities to succeed in life experiences such as social mobility.

In discussing race, it is important to include a group that is often overlooked. Discussions of race and its impact on the education that some students receive would not be complete without mention of a non-minority population that literally falls through the cracks educationally. Heilman (2004) discusses ethnic Whites who are marginalized because of their roots in Appalachia. She states that they are looked upon with a "negative social opinion...carried on from colonial days to the present" (p.68). Because white ethnicity is rarely characterized as "different", a discussion of whiteness as a racially oppressed group in education is brought to light and attention drawn to the lack of literature on this group. Lastly, she asserts that researchers tend to "focus more on the construction of white privilege than white diversity" when a discussion of whites does occur in the literature (p.71). Students who are racially classified as White Applachians experience the same school failures as those from minority backgrounds and are overrepresented in special education programs.

\section{Class.}

According to Merriam-Webster's Dictionary ( $10^{\text {th }}$ ed.), class refers to a group sharing the same economic status or rank. It can be related to a person's work experience or economic and social position as compared to others. In relation to education, class is one of the most important factors affecting educational systems today. When describing a person's class, typically three categories are used: high, middle, and low socio-economic status (SES). High class individuals are assumed to possess wealth thus, have the ability to live well above the average person in society. It 
can be argued that the majority of the population is middle class individuals, yet some assert that individuals considered working class or low SES do not fit into this category. Middle class individuals can be classified as having enough resources to live above poverty. The term poverty relates to class as it identifies when individuals do not possess the necessary resources to live above a specific standard outlined by the federal government, thus making them low class. It is a term that is impossible to ignore when $13 \%$ of the total population in the U.S. lives in poverty and $18 \%$ of the population under age 18 is living in poverty (U.S. Census Bureau, 2007). Park, Turnbull, and Turnbull (2002) stated that $28 \%$ of children with disabilities aged $3-21$ are living in poverty. Conversely, only $16 \%$ of children in same age range not having disabilities are living in poverty.

Christie (2009) says that as the percentage of low-income students increase so does the challenge of meeting their needs. Park, Turnbull, and Turnbull (2002) found that it is "increasingly evident that poverty has a tremendous impact on the educational results of all children, including those with disabilities" (p. 152). Poverty affects a child's well-being physically, mentally, and emotionally. Educationally, these students are behind before they get started because often times the mother did not receive adequate. The child may have been born into an environment where a lack of resources made adequate nutrition nearly impossible. Households such as these may place more focus on daily survival as opposed to nurturing components such as communication, literacy, or adequate medical attention for example. Skiba et al. (2008) maintain that "risk factors associated with poverty result in increased academic underachievement and emotional/behavioral problems among minority students, thus 
increasing the risk of minority referral to special education" (p. 272). Christie (2009) asserts "Learning is the way out of poverty.....Schools are places of learning" (p.543). Unfortunately, the students born into poverty are concentrated in the "struggling schools" (Pogrow, 2006). Despite efforts to combat these factors, it is hard to overcome the reality and "it is naïve to believe that poverty has no role in affecting educational outcomes" (Townsend, 2002, p. 729).

\section{Disability.}

It is first appropriate to discuss the underlying theme that this review rests upon. In the field of special education, disability can take on many meanings and thus, is a diverse term. Although many recognize the fact that people with disabilities are all around them, disability is often excluded by those focusing on diversity issues (Wallace, 2001). Skiba et al. (2008) discuss the history, status, and current challenges of special education, including the issue of equity and special education in today's society. Gallegos and McCarty (2000) state that "learning about disability goes beyond alleged physical, behavioral, and psychological differences...it also has symbolic meaning in terms of what society values and what it degrades" (p. 265). They argue that special educators cannot be effective teachers unless they possess an appreciation of differences and are able to provide appropriate instruction to each student based upon their individual needs and not their own personal beliefs or those held by others around them. Defining needs of students from diverse backgrounds with disabilities is a difficult process as each case is unique. These needs are further compounded when there seems to be a correlation that exists between all of the background characteristics of these students with disabilities. 


\section{Intersection of Race, Class, and Disability}

In reviewing literature on the student diversity characteristics race, class, and disability, it is evident that a connection between the three exists. Increased attention has been given to the correlation between an individual's race and/or the class in which their family exists and the increased likelihood of them being placed into special education over the past few decades. Many researchers [as cited in Park, Turnbull, and Turnbull, 2002, p.152] have performed demographic studies and found that a relationship exists between class and risk for disability (Fujjiura \& Yamaki, 2000; Kaye, La-Plante, Carlson, \& Wenger, 1996; Seelman \& Sweeney, 1995). Hodgkinson (1995) [as cited in Skiba et al., 2008, p. 273] characterizes the overlap of race and class bluntly by stating that he believes many have come to believe that race has simply become a "proxy" for class. Others believe that the way in which these characteristics intersect in the educational system is not coincidental. For example, Ferri and Connor (2005) believe that schools use labels in an effort to "resegregate along race and class lines" (p. 459). Similarly, Reid and Knight (2006) assert that minorities are overrepresented in special education and underrepresented in higher education as a result of "historical legacies of racism, classism, sexism, and ableism" and their continued influence on the practices of educational structures in this country (p. 21). In today's' society, children are continually marginalized, especially those who are poor and perceived to be different. Therefore, Manning and Gaudelli (2006) issue a caution towards the process of early identification of students of color and those from impoverished backgrounds. They assert that a reduction in the number of students identified can minimize the process of resegregation in today's schools. 
The impact of this intersection is best explained in a discussion by Grossman (1995), who identified three major problem areas pertaining to this intersect. He stated that poor and non-European students are misrepresented - both over-enrolled and under-enrolled in special education, the services that they receive are often culturally inappropriate, and those with limited English proficiency or those speaking a nonstandard English dialect experience linguistically inappropriate services" (p. 2-3). The need for quality educators in the classroom has never been greater and more teachers are needed who have an understanding of how students from minority and poor backgrounds function so that they, too, can receive adequate and appropriate instruction. Shealey et al. (2005) discuss how "students of color and those from impoverished settings remain at greater risk for placement in special education (p. 116). Additionally, they make reference to the Brown decision (1954) and its relationship to special education, pointing out that students of color and students with disabilities continue to be face barriers in their quest for equal access within the educational system despite the federal mandates in existence. Reid and Knight (2006) also take an historical perspective in their discussion of disability studies and the need for more attention to how the intersection of race, class, and disability impacts the performance of students with disabilities.

\section{Impact of Student Diversity Characteristics}

Because of student diversity characteristics such as race, class, and disability, many students are finding it harder to navigate an educational system that has been slow to respond to the changes of the society it was designed to serve. The methods in which students are educated have not aligned with the various demographical shifts of 
today's classrooms. Students have become more heterogeneous providing for rich experiences culturally, linguistically, and socially. However, the way in which students are being served educationally, most specifically those possessing any type of characteristics of diversity, places them at a greater disadvantage. Teachers are faced with managing students with differing racial, cultural, religious, linguistic, economical, and socio-economic backgrounds to name a few, while still being expected to ensure that all students are able to meet the educational standards outlined by their districts, states, and nation. This has caused a great strain on the teaching field.

Special education teacher shortages across the United States, in urban and rural areas, are critical, and chronic (Brownell, 2005; Brownell, Bishop, \& Sindelar, 2005; Brownell, Hirsch, \& Seo, 2004; Boe, Cook, \& Sunderland, 2008; Cook \& Boe, 2007; Gehrke \& Murri, 2006; Ingersoll, 2001; Johnson, Humphrey, \& Allred, 2009; McLeskey, Tyler, \& Flippin, 2004). Some researchers believe that these shortages have begun to affect the integrity of the field because of the number of licensed teachers leaving the field (Nougaret, Scruggs, \& Mastropieri, 2005). Regardless of the reason, the fact that so many trained teachers leave the field on a regular basis has caused many districts to have an unwelcome number of unlicensed teachers filling the vacant positions. Thus, a review of data available from the following was necessary to examine the disparity between available positions and available teacher education program graduates: U.S. Department of Education Office of Special Education Programs (OSEP), National Center for Education Statistics (NCES), National Comprehensive Center for Teacher Quality and Public Agenda, and the American Association for Employment in Education (AAEE). From this, it is evident that there is not only a need for more teacher education 
program graduates to select actual special education teaching positions but also the need for them to remain in those positions. In looking at the research, some key factors emerged that need further review. They are supply and demand, recruitment and retention strategies, and attrition.

A "balanced" supply and demand in any occupation allows candidates and employers alike to experience feelings of confidence (AAEE, 2007). However, in some fields, an imbalance exists without a clear explanation. Special education is one field in which this occurs. Brownell, Hirsch, and Seo (2004) stated that "few problems in special education are as vexing as the chronic undersupply of special education teachers" (p. 56). According to the 2008-2009 Occupational Outlook Handbook published by the U.S. Department of Labor Bureau of Labor Statistics, job prospects for a special educator are expected to increase by $15 \%$ from 2006 to 2016, which is much faster than the average for all other occupations. Yet, the shortage of special education teachers in the U.S. is at a dangerous high. The shortage has become such an issue that organizations such as The National Center to Improve the Recruitment and Retention of Qualified Personnel for Children with Disabilities and The National Coalition on Personnel Shortages in Special Education and Related Services (NCPSSERS) have been formed, with the mission of addressing the shortage and developing ways to combat them. According the NCPSSERS, less than $20 \%$ of the 17.5 million students with special needs actually receive adequate services. Given that students with special needs require educators who can provide instruction according to their specific needs, NCPSSERS developed a website with the American SpeechLanguage Hearing Association to help address the shortages and help provide districts 
with data to overcome barriers causing the shortages. The AAEE's 2007 Educator Supply and Demand in the United States report states "all 10 special education fields reported the highest demand in three years" (p. 3). Despite the high demand, significant shortages still exist nationwide and an examination is needed into the reasons why there are still so many available positions in the field of special education.

Some authors believe the factors that affect teachers' decision to refrain from entering into the special education profession are still unknown (Brownell, Hirsch, \& Seo, 2004). McLeskey, Tyler, \& Flippin (2004) conducted a review of the literature on the supply and demand of special education teachers and found that each year, $40 \%$ of the total population of beginning teachers in the field are recent graduates of teacher education programs and that these programs are a "major source of beginning special education teachers" (p. 13). They continued that although the production of special education teachers from teacher education programs increased by $21 \%$, this growth is not enough to affect the current special education teacher shortage crisis currently in effect. Cook and Boe (2007) point out that "about $75 \%$ of teacher education program graduates are already employed as teachers upon graduation", making only $25 \%$ of them available for open positions (p. 218). Even so, the majority of the 30,000 open special education positions needing to be filled by the beginning of every year will be filled by uncertified teachers as reported by Brownell, Bishop, and Sindelar's (2005) citation of IDEA data stating that " $12.3 \%$ of the 13.6 million special education teachers lack certification in special education" (p. 9).

Even with supply and demand in balance, the field of special education will still grapple with filling all available positions. More quality individuals need to be recruited 
into the field and retained to fully serve the large population of students requiring specialized services. Although much attention has been placed on the availability of teaching positions in inner-city and urban areas, some authors have focused their discussions on pre-service students and rural areas where the intersection of race, class, and disability can be cited as affecting the student population just as much, if not more (Sundeen \& Wienke, 2009; Tyler, Cantou-Clarke, Easterling, \& Klepper, 2003). These researchers cited isolation, pay, and training opportunities as barriers to getting students to choose teaching positions in rural areas. Yet their main suggestion for overcoming this dilemma, which was funding, can also be effective in all areas nationwide. In order to recruit and retain effectively in the field of special education, grant monies must be sought out from both the state and federal levels to attract a diverse pool of pre-service students who are adequately prepared to teach diverse population and who have a high commitment to teaching. Brownell, Hirsch, and Seo (2004) have suggested that a method where states develop a type of personnel database in which they track teachers from the time they enter until the time they leave the classrooms would be effective in improving the supply and quality of special educators.

According to Brownell, Bishop, and Sindelar (2005), schools serving low SES and highly diverse students struggle with recruitment and retention despite the salaries offered. Graduates who are considered "highly qualified" often refrain from teaching in these areas where the need is so great. Or, teachers who are considered effective choose to teach in areas where resources are plentiful, parental involvement is a norm, and students have less behavioral difficulties. Often, schools that are considered high 
need schools are located in areas that are considered rural, urban (inner-city), or where the special needs population is high. Further compounding this issue is when these particular characteristics exist in conjunction within a specific school context. For example, recruiting highly qualified or effective special education teachers to rural schools is a difficult process. In discussing their findings from a study investigating the impact of the highly qualified requirement on recruiting special education teachers in rural WV, Courtade, Servilio, Ludlow, and Anderson (2010) report that "districts have struggled to find highly qualified teachers, sometimes making difficult decisions" (p. 3). These areas, which are in the greatest need for the best and brightest teachers, are left with filling open positions with teachers who are uncertified or who teach an area outside of their certification.

Attrition is a concern when looking at the demand for teachers, especially in the special education field where a "revolving door" effect often occurs. As Brownell, Smith, McNellis and Lenk (1995) point out "without an understanding of teacher attrition, states may attract teachers to special education only to lose them after a few years" (p. 84). A greater concern in this field is the even higher attrition rate of beginning teachers (Boe, Cook, \& Sunderland, 2008; Gehrke \& Murri, 2006). Brownell, Hirsch, \& Seo, (2004) reported that beginning teachers were the "most vulnerable to attrition" (p.57). Thornton, Peltier, and Medina (2007) assert that "Teachers who are not well prepared for their job are more likely to quit prematurely" (p. 236). This type of loss can be detrimental to those students who respond negatively to transition. Students from diverse backgrounds can come to the classroom with a variety of issues that can affect their educational productivity; therefore, without a teaching force that is dedicated and 
consistent, these same students experience are set to fail. Although, many open positions are due to the numerous special educators who switch to general education, change careers altogether, quit, or retire, steps can be taken to reduce the number lost. In order to positively affect the overall status of special education, the attrition rate needs to decrease significantly. In order for this to occur, pre-service students must come out of teacher education programs fully prepared and ready for teaching these students with diverse needs. Teacher education programs must examine their role in ensuring that this occurs.

\section{Teacher Education Programs}

\section{Pre-service student expectations of the field.}

It is expected that the first year in any job will be difficult because of normal transitional issues. It is important to examine pre-service teachers' perceptions in order to determine what role, if any, teacher education programs can play in increasing the number of pre-service students in special education entering the teaching field. Preservice students in teacher education programs are aware of factors that will affect their transition from student in the classroom to teacher in the classroom and yet many still choose to take a teaching position upon graduation taking into account some of these difficulties. Otis-Wilborn, Winn, Griffin, and Kilgore (2005) describe the first year of any teacher's professional career as being the "most challenging" (p. 143). Pre-service students are required to participate in a field experience and can understand this description. However, often times, they wrongly equate that teaching field experience with that of an actual classroom and are often overwhelmed that first year. In a report entitled Teaching in Changing Times, Laine (2008) discussed findings from her study of 
first-year teachers to show how many of those teachers reported the "realities" of today's classrooms, how they were "assigned the 'hardest-to-reach' students" , and what effect this had on their willingness to remain in the field.

Pre-service students understand that today's classrooms have changed demographically and may also feel that they are trained and capable of teaching students who require the most assistance, namely those possessing the diversity characteristics of race, class, and disability or any combination of the three. AmreinBeardsley (2007), in a study of highly qualified teachers, sought to determine the factors that would entice or prevent experienced teachers from teaching in some of today's most challenging schools. Her respondents reported the number one factor that would both entice and deter them was the quality of the principal. Although they indicated salary was the most important factor next, their third factor was being able to serve as a "teacher educator" to inexperienced teachers. Gehrke and McCoy (2007) found that beginning special education teachers who remained in the field after their first year reported their reason for staying as having access to a "network of supportive persons and resources" (p. 38). Beginning special educators also reported that induction programs made a difference in their experiences that first year (Billingsley, Carlson, \& Klein, 2004; Gehrke \& McCoy, 2007). These studies suggest that school environments that contain individuals, from the principal down, who are caring, concerned, and committed to the students that they serve may influence special educators' decisions to remain in their teaching positions.

A study comparing pre-service and novice special educators found that preservice students possess an accurate perception of what their roles in the classroom 
would look like (Wasburn-Moses, 2009). They found that pre-service students' expectations of what they would encounter in the field of special education was often more aligned with actual teaching situations than reported by their practicing counterparts. This finding suggests that teacher education programs are preparing future special educators for the realities of today's classrooms -more co-teaching and collaboration. Program graduates often report positive experiences during their teacher education programs and state that they feel well-prepared, but still fail to enter the teaching profession.

A study conducted by Alastuey, Justice, Weeks, and Hardy (2005) concluded that teacher education programs are preparing those who are interested in the profession, but do not understand why some of their students do not make this their career choice upon graduation. Rots, Aelterman, Vlerick, and Vermeulen (2007) discuss this quandary in their attempt to determine a relationship between teacher education program graduates and their decision to enter the teaching profession. They found that teacher education program graduates who did not choose to enter the teaching profession may possess a positive view of their preparation and of the curriculum but that they "may have acquired more generic professional qualifications" providing them with more options for career choice (p. 553). Preparation of pre-service students in teacher education programs has been examined for years. More examination is needed to ensure that a higher percentage of prepared special education teachers enter the field. In their comparison study of special education teacher preparation versus general teacher preparation, Brownell, Ross, Colon, and McCallum (2005) note that research on special education teacher education is lacking or 
nonexistent (p. 242). Therefore, the review of programs focused mainly on articles pertaining to teacher education programs in general.

\section{Program review.}

Many schools of education have recognized the need to improve their teacher education programs to align with the skills and practices needed in today's classrooms. In fact, several educational researchers emphasize a need for alignment in teacher education programs and their preparation of school district personnel (Gay, 2000; Townsend, 2002; Wallace, 2001). In the past few decades, an examination of how teacher education program graduates are prepared, more specifically the strategies they are taught to address the changing demographics of today's classrooms has come to the forefront of many agendas in the field of education. Levine (2006) argued that many teacher education program graduates are inadequately prepared to become effective educators stating that $62 \%$ of teacher education alumni surveyed reported that their programs did not prepare them to "cope with the realities of today's classrooms" ( $p$. 64). Several authors have addressed the growing need for teacher education program reform in areas such as curriculum and field experience; however, these conversations are still taking place about exactly how to implement changes so that pre-service students are better prepared to meet all students' needs (Brown, 2007; Cannella \& Reiff, 1994; Cochran - Smith, 1995; Darling-Hammond \& Berry, 1999; Melnick \& Zeichner, 1998; Menter, 1989; Milner, 2006; Swartz, 2003).

In response to the growing concern over the need for excellent teachers in today's classrooms, The National Center for Educational Statistics (NCES) (1999) identified the elements of teacher preparation/qualifications and teaching practices as in 
need of the biggest reform. In his report, Educating School Teachers, Levine (2006) conducted a survey of 28 teacher education program graduates and found that over half not only felt unprepared to address the students' needs, but felt that the faculty as well as the curriculum was responsible for their deficits. He identified several factors that contribute to this uncertainty: differing program lengths, undergraduate vs. graduate programs, a gap between theory and practice, and limited field work experiences as affecting teachers' ability to handle the diverse composition of today's classrooms. In another study of 99 respondents, Milner et al. (2003) found that pre-service students were unsure as to how they felt about the infusion of activities that would provide them with more exposure to and a better understanding of student diversity characteristics; the researchers felt lack of experience with students from diverse backgrounds was responsible for these feelings indicating a continued need for a search for model programs. One study examining pre-service students' beliefs about issues of diversity also included personal accounts from their first year on the job. Students reported that they actually revised their initial viewpoints regarding urban students and provided atrisk students with opportunities to learn and succeed as a result of numerous and diverse clinical experiences (Yost, Forlenza-Bailey, \& Shaw, 1999).

First-year teachers feel unprepared to teach diverse student populations for the most part because teacher preparation programs "remain bastions of traditional, Eurocentric models of education, and therefore, special educators may be ill-equipped to provide culturally responsive curriculum and instruction for students who are culturally and linguistically diverse (CLD) and have disabilities" (Green, 2007, p.12). Gaining appropriate theory and practice in a preparation program is especially important for 
teacher education programs in special education since students from diverse backgrounds continue to be overrepresented in those classrooms. Blanchett (2006) argues that additional research is needed in order to examine the use of inappropriate and culturally unresponsive curricula and inadequate teacher preparation and their relationship to the problem of disproportionality over time and in a variety of settings. Pohan (1996) asserts that 'if programs fail to address teachers' personal beliefs, particularly those related to diversity and diverse others, it is unlikely that schools will ever meet the challenge of equity and excellence for all students" (p.67).

Many universities are gaining an understanding of the need to revamp their teacher education programs in an attempt to better prepare program graduates. Several have been successful in not only providing pre-service teachers with the necessary curriculum and field experiences, but also transforming their thought processes along the way. Ford, Pugach, and Otis-Wilborn (2001) identified program changes needed to prepare pre-service students to teach students with disabilities. They were strongly in support of a continued relationship between general education and special education and thus, developed a fifth-year post baccalaureate program for pre-service students interested in teaching students with special needs in order to widen their ability to prepare more students to meet the changing needs of today's classrooms. Many other authors also discussed program changes that would allow preservice students to gain more knowledge, understanding, and experience in teaching students from racial, cultural, and linguistically diverse backgrounds (Barnes, 2006; Brown, 2004; Milner et al., 2003; Milner, 2006; Zeichner et. al., 1998). 


\section{Factors Affecting Job Choices}

The factors that pre-service students use in selecting an initial teaching position may be innate, related to background experiences, or a direct result of a teacher preparation program. Reynard (1957) focused on the factors that influence beginning teachers' selection of that first teaching position and found factors that are still prominent today, such as salary scales and school demographics and locations. It is evident from the dates of these studies, that we haven't made much progress in this area over the past $50+$ years. The basis for this study rests upon the fact that there is ample research focused on the reasons that teachers choose teaching as a profession or why they choose to leave the field, yet little research that focuses on the reasons preservice students choose the jobs that they do upon graduation. Chapman (1984) discusses social learning theory of career decision making (Krumboltz, 1979) and its effects on teacher retention. He stated that Krumboltz's theory describes how one chooses their career path and that is based upon "interaction of personal characteristics, previous behavior (learning), and environmental determinants" (p. 645).

The desire for money and status, leadership, and the ability to use their skills are factors outlined by Young (1995) as factors associated with high-achieving pre-service students' decision to choose an alternative career upon graduation from a teacher education program. She also pointed out the need for more research to determine how to retain these bright students in the teaching field.

Hodkinson and Sparkes (1997) noted the lack of research on career decisionmaking in their discussion of three theories used to explain why individuals choose careers: trait theory, developmental model, and social learning theory. Their data 
showed that some rejected jobs based upon personal reasons or their decisions were "pragmatic rather than systematic" (p. 33). It may be that a number of factors play into the reasons that career decisions are made and more research is needed to better understand this phenomenon. More recently, authors have looked at teaching commitment as a factor in this dilemma (Rots et. al., 2007; Rots \& Aelterman, 2008). They felt that an individual's personal attachment to a career such as teaching directly affects whether they choose to work in that field or not. Those factors referenced above, such as personal background characteristics, continue to play a role in these decisions, although they are not nearly as important as one's initial motivation for teaching.

An examination of research focused on other areas such as nursing, music education, and agriculture education showed that those fields are just as affected by teacher attrition. White (1999) concluded that individuals are unique in their development of the world around them and they gain that view based upon personal experiences. This conclusion pertains to teacher education because pre-service students, too, need adequate teaching experiences to determine the exact position that is right for them. Intrinsic and extrinsic factors were found to motivate career choice in a study of graduates certified to teach agriculture education. According to Harms and Knobloch (2005), theories that examined needs and self-efficacy were most helpful in determining factors that affect pre-service students' decision to teach in their field. Similar factors were found by Hellman (2008) who found that pre-service music education students cited money, lack of confidence in teaching skills, and an overall 
desire to do something else as main reasons for not entering into a music teaching career.

Regardless of the field, it seems as if pre-service students experience similar reservations about choosing a position within or outside of their field upon graduation. Because of the limited amount of research on this topic, preparation programs are seemingly slow to make changes that would rectify this dilemma, therefore, leading to the increasing numbers of vacancies. As Rots et al. (2007) stated, "Additional research is needed to account for the influence of other antecedents of graduating teachers' teaching commitment and entrance into the teaching profession" (p. 555). Therefore, research is needed into the characteristics that must be present in a teaching position in order for a teacher education program graduates to see it as ideal.

\section{Conclusion}

As a result of a changing student population, $21^{\text {st }}$ century teachers have been forced to not only adapt, but also adopt new sets of teaching practices. After years of research and discussion, educators still grapple with how to best accommodate those who are "different" or those who do not fit the norm. Interestingly, this norm is changing rapidly and yet the way in which the average classroom is structured (teaching methods and expectations for those coming from diverse backgrounds) still follows the dominant, White middle-class norms outlined decades ago. As pre-service students go into the field, it is important to determine how best to prepare them to meet the needs of all students. Teacher education programs must assess how the deficits and align themselves with the changing demographics of today's classrooms. 
Little is known about how and why teacher education in special education program graduates select an initial teaching position (McLeskey, Tyler, \& Flippin, 2004). This study was designed to examine whether pre-service students have certain preferences for or aversions toward teaching positions based on characteristics of student diversity. Additionally, it explored whether experiences within a teacher education program can affect the attitudes, beliefs, and actions of the program's graduates in selecting a teaching position. 


\section{Chapter Three}

\section{Method}

\section{Purpose of Study}

The purpose of this study was to explore the extent to which pre-service teacher education students considered the presence or absence of specific diversity characteristics and if it had any influence over their choice of a hypothetical teaching position. The study examined the positions that participants chose as most and least ideal and the characteristics of those hypothetical teaching positions. An examination was also made regarding the way in which they ranked the other positions and the characteristics present in all of the positions. Throughout this study, an attempt was made to determine what factors were reported as having affected these participants' decision making in order to understand the choices that they would make as they neared choosing their initial teaching position upon graduation.

\section{Research Questions}

This study attempted to answer the following research questions:

RQ1: What types of hypothetical teaching positions do pre-service students in special education choose based upon the presence or absence of specific characteristics associated with student diversity, namely race, class, or disability?

RQ2: What factors do pre-service students in special education report as influencing their choices when selecting an ideal hypothetical teaching position?

\section{Participants}

The researcher chose to use purposeful sampling because it "focuses on selecting information-rich cases whose study will illuminate the questions under study" 
(Patton, 2002, p. 230). Since the study focused on special education, the researcher identified the 18 pre-service students in the 2010 graduating class who had selected the content area of special education while enrolled in a five-year teacher education program at a Research University Classification (High Research Activity) institution for participation in this study. Unlike many other $4+1$ programs, these pre-service students graduated with both a bachelor's degree in a content area and a master's degree in education. The demographics of this group were as follows: 15 female, 3 male; all of Caucasian background, and 17/18 Elementary Education majors. The age range of the participants was 21-23 years old, with mean $=22.1$ and mode $=22$. The participants were residents of five different states: $\mathrm{WV}-10, \mathrm{PA}-5, \mathrm{MD}-1, \mathrm{VA}-1$, and $\mathrm{FL}-1$. These students were selected because they are trained to understand and accommodate the various characteristics of student diversity in terms of race, class, and most importantly, disability and will be referred to as "participants" henceforth.

\section{Research Design}

As pre-service students approach graduation, their minds most likely are on the next step in life-- securing a teaching placement. As the season of job searching gets underway, those pre-service students who desire to teach begin to consider their options. Some may prefer a position in their home town while others assess positions based upon specific variables such as job salary, class size, a signing bonus, or school location/neighborhood. Thoughts and opinions on student diversity in their ideal job placements could also come into play during the job selection process. Since this study set out in search of a new phenomenon and the amount of related research available to support this particular phenomenon was limited, it can be defined as exploratory 
research. The overall purpose of this study was to explore what characteristics preservice students consider and the factors that affect those considerations, this exploratory study used a qualitative approach since little is known about the factors that pre-service students consider in selecting teaching positions. Creswell (2003) offers support for a qualitative approach to be used in instances when a "...phenomenon needs to be understood because little research has been done on it" (p. 22).

To answer the specific research questions outlined, a basic interpretive qualitative design was chosen. When the researcher serves as the instrument for collecting data, Merriam and associates (2002) suggest that the researcher will be able to understand "...how participants make meaning of a situation or phenomenon..." (p.6). Basic interpretive design is especially appropriate to study this phenomenon because, according to Merriam and associates (2002), “...people interpret everyday experiences from the perspectives of the meaning it has for them" (p. 37). The researcher felt that this research design allowed for data to emerge relative to each participant's thoughts. The importance of these data for the field of special education is to a) identify the type of job that study participants deem ideal, but also b) to identify areas for restructuring of and/or additions to teacher education course content to ensure that participants are more likely to consider themselves prepared and willing to teach students from diverse backgrounds.

\section{Role of the Researcher}

Since the researcher is the primary instrument in any qualitative study, background information as well as previous research training and experience is provided. Patton (2002) discusses the importance of including information about the 
researcher and notes that "background characteristics of the researcher (e.g., gender, age, race, and ethnicity) may be relevant to report" (p. 566). Although growing up as an African-American female in a small town in West Virginia, it wasn't until later in life when the researcher noticed differences of opinion regarding diversity characteristics. After being trained as a special educator, the researcher gained experience while working in the field (in resource classrooms) and also acquired valuable observation and analysis techniques while working as a behavior specialist. While completing the required coursework for the doctoral program at West Virginia University, the researcher had the opportunity to take an additional qualitative research course to strengthen my ability to conduct research of this nature. Research experience was gained while conducting a day-long study at WVU-Parkersburg under the supervision of the qualitative research course instructor where the researcher followed an interview protocol and used various probing methods to gain insight into the phenomena being studied.

The researcher's interest in the population chosen for this research study evolved while teaching numerous special education undergraduate and graduate courses. It became apparent early on that she did not possess a cultural understanding of the typical student in teacher education programs and therefore experienced difficulty in trying to understand her students. When leading class discussions, the researcher realized that the students' views on diversity in general were different from those of her own. Initially, the researcher believed that most of the students from West Virginia wanted to remain in the state yet would rather not teach students who exhibited characteristics of diversity such as disability, race, or class. She also found that those students whose views were most aligned with hers were from outside of the state, and 
more specifically areas where greater student diversity existed. In an attempt to gain a better understanding of students and conduct class discussions that allowed them to examine their views on student diversity, the researcher employed various teaching strategies. With each subsequent course taught, at least one student who had an interest in teaching diverse student populations evolved. At this point, the researcher was able to share some personal experiences since her first teaching placement out of graduate school was in the Washington, D.C. metropolitan area. Although the researcher did not feel as if growing up in a small town in West Virginia and attending college in that same state provided the tools necessary to adequately understand the culture of students taught in that first position, the situation emerged as a challenge.

\section{Data Collection}

\section{Instrumentation.}

The interview protocol consisted of a five page document with page one asking for demographic information and the remaining pages containing six hypothetical teaching positions and a series of probing and follow-up interview questions. These teaching scenarios were developed with a major emphasis on three areas of student diversity: race, class, and disability. To develop realistic teaching positions, the researcher reviewed statistics on real school districts to assist in the development of the series of scenarios. Actual characteristics such as racial composition, free and reduced lunch percentages, number of students with disabilities served, and city/county demographic data were used in each hypothetical teaching position. Other characteristics were embedded within each scenario to acknowledge that other factors exist that individuals may consider when determining whether a teaching position best 
suits their needs. Job salary was included to help discern if the participants made selections based upon salary alone or if other factors play a role in the position that is ultimately chosen. Careful consideration was used in developing the scenarios to make them as neutral as possible so as not to raise any questions as to the purpose of study with participants. The researcher spent ample time with all of the characteristics in order to develop hypothetical teaching positions that most accurately reflected a sample of possible jobs available today in the teaching field.

In order to ensure content validity, the original scenarios and follow-up questions were submitted via email to several colleagues for their review and thus feedback. The selected reviewers were chosen because of their work in the field of special education and knowledge of characteristics representative of actual teaching positions. Each reviewer was provided background on the research study questions, the purpose of the scenarios, and what the researcher hoped to gain from their reviews. Reviewers were asked to comment on how realistic each hypothetical teaching position was. The feedback focused mainly on adjustments of the percentages of racial compositions, free/reduced lunch population, and students with disabilities served. Reviewers felt that some of the statistics were elevated. Other feedback focused on choosing appropriate word choice, such as "upper-middle class" and "urban". Removal of certain words such as "only" before percentage of students with disabilities made that specific statistic more objective. The revised scenarios and interview protocol used can be found in Appendix A. 


\section{Procedures.}

A protocol was submitted to and approved by the WVU Institutional Review Board for Protection of Human Research Subjects (IRB) in the Office of Research Compliance. Prior to the data collection, the researcher obtained approval from a special education faculty member to begin the initial phase of data collection in his course in which all participants were enrolled during the spring semester. Once consent was gained, a scheduled time was agreed upon by the researcher and the faculty member to begin data collection. After the purpose of the study was explained and all 18 targeted participants agreed to take part in the study, they were asked to sign a consent form. After the researcher reviewed the expectations with the participants, each was asked to complete the demographic information on the response sheet for reference later during the interviews sessions. The researcher then instructed the participants to proceed in ranking the attached scenarios in terms of the position they would be most likely to choose (1) to the one that is least likely their ideal beginning teaching position (6) and all of the rest in between. Participants were asked to use the space provided under the scenarios to record their initial thoughts, reactions, questions, etc. These anecdotal notes served as reflective writings during the analysis phase. Each interview protocol was coded with alphabetical letters so that their scenario rankings can be referenced during the individual interviews.

Miller and Dingwall (1997) cautioned that the information gained through interviews may not be a participant's total reality pertaining to the subject (p. 60). Patton (2002), however, states that in order to "capture" some glimpse of this reality, interviews can be used "...to capture the complexities of their individual perceptions and 
experiences" (p.348). At the end of the initial phase of data collection, contact information from the demographic section of the protocol administered in the first part of the this phase was used to schedule 30 minute individual, face-to-face follow-up interview sessions, which were held on campus in an identified classroom. The goal was to arrange this interview schedule so that all interviews could be completed over a two week time span. However, because the last semester is so busy and spring break, a conference, and a teacher fair interfered with scheduling, an additional two weeks were needed for data collection. For each day of data collection, interviews were set to begin as early as 9:00 am and ended at approximately 4:45 P.M. With such a prolonged interview schedule, concerns were present surrounding the possibility that the participants would discuss their individual sessions with peers and thus confound the results of these data obtained during these interviews, yet that didn't appear to be the case.

Since interviews are commonly used by researchers to gather personal accounts of some phenomenon (Freebody, 2003; Miller \& Dingwall, 1997) interviews were conducted with each participant with the belief that some insight into "...multiple realities" (Stake, 1995, p.64) of the actual ranking data. In each interview session, the participants were asked to explain their reasoning for ranking the hypothetical positions, pointing out the pros and cons of each scenario. The researcher probed to determine which hypothetical teaching positions participants felt could be a possible job, asking them to identify the specific characteristics that needed to be present to qualify as an ideal teaching position. This provided insight into their perspectives on student diversity and if/how those perspectives affected their rankings. Their statements were later 
compared to their actual comments on the ranking sheet. Upon completion of the scripted probing questions, participants were asked to share any final comments regarding an ideal teaching position in terms of the characteristics of the student population, beginning salary, incentives, urban vs. rural setting, and any other factors relevant to their selections.

Consent for the use of a recording device (tape recorder) to audio-tape each session was gained at the beginning of each individual session. However notes were also recorded during each interview session in the research journal as an additional method to ensure accuracy during data analysis. Each of the interview sessions were transcribed by a third party. To the extent possible, verbatim statements were recorded in the research journal for a product that is "... richly descriptive" (Merriam and associates, 2002, p. 5) and were compared to the interview transcripts to ensure all data were present for analysis.

\section{Data Analysis}

Unlike quantitative data which is described in terms of numeric values, the term "qualitative data" refers to the quality of something and, in this study, it referred to the words, phrases, and statements collected during the interview process since interviews yield direct quotations from people (Patton, 2002). Patton (2002) also described a process of "...identifying, coding, categorizing, classifying, and labeling the primary patterns in data" (p.463), which was necessary with a study of this nature. In order to sort through the massive amounts of data produced from this study, the researcher used a data analysis technique outlined by Harry, Sturges, and Klingner (2005) in which these data were analyzed using a visual model called a data analysis map (Figure 1). 
This map is intended to be read from the bottom to the top to "reflect visually the inductive nature of the process" (p.4).

\begin{tabular}{|l|l|l|l|}
\hline SIX LEVELS OF ANALYSIS & DATA & DATA & DATA \\
\hline
\end{tabular}

6. Theory:

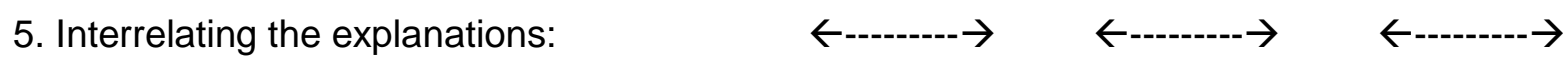

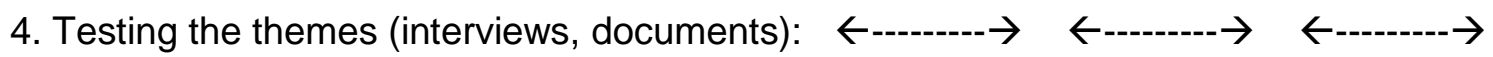

3. Themes:

2. Categories:

1. Open Codes:

Figure 3.1. Data Analysis Map. Two-directional arrows indicate nonlinear connections among items. (Harry, Sturges, and Klingner, 2005).

A research journal was kept to record all reflections during the data collection and analysis phases. According to Hatch (2002), this type of journaling allows the researcher to reflect and develop interpretations at the end of each interview session. The research journal provided opportunities for the researcher to address any and all biases, understanding the importance of acknowledging her own subjectivity as a researcher during these analyses. Reading through all of the research notes and beginning to make notations in them, across them, and all throughout them during the analysis phase enabled the researcher to create links between all data sources (scenario rankings and participant anecdotal notes, demographic information, interview 
transcripts, and research journal). Wiersma and Jurs (2005) point out that through the organization of data collected "...there should be data reduction" and call this process "coding" (p.206). As maintained by Bogdan and Biklen (2007), sorting through data should consist of looking for certain words, phrases, and events that are reoccurring.

Throughout analyses of these data, the researcher took caution to ensure that all of the research questions were addressed and therefore, answered. Initially, the researcher examined all scenario rankings to determine which hypothetical teaching position the participants chose most frequently as their most ideal, least ideal, etc. in order to answer RQ1- which types of hypothetical teaching positions do pre-service students choose. To begin the process (level 1 of the data analysis map), the researcher read interview transcripts, looking for key points made by the participants that emerged out of these data. As the interview transcripts were read and re-read, notations were made regarding specific words, phrases, or sentences that could be developed into a set of "open" codes. Once this process was complete, the researcher reviewed the transcripts again and the markings were put onto cards to be sure that all codes were recorded. There was a total of 45 data codes recorded. It is important to note, that some codes fit into more than one coding category. For example, the word (diversity) was related to more than one code based upon the context in which it is used (Bogdan \& Biklen, 2007). The next stage of analysis was Level 2 of the data map, or categories. The researcher continually reviewed the codes identified in level 1 , "comparing and contrasting...to identify the common features" (Harry, Sturges, \& Klingner, 2005, p. 5) to form "conceptual categories". These 7 categories developed were also recorded onto cards and the data cards sorted under them. 
In order to begin the next phase of analysis, a search for patterns within the participants' rankings to determine what hypothetical teaching position was chosen the most and least and the characteristics of student diversity present in each of those scenarios took place. At this point, the researcher began the process of identifying themes that emerged within these categories (level 3). Validation of those themes occurred by an examination of these data from the notes that each participant recorded during their rankings as well as that recorded from the interviews. In looking at the factors that the participants reported as influencing their choices (RQ2), the researcher's analysis through the first four levels of the data analysis map determined what those factors were and thus, what themes emerged. They were then tested against the actual data from the ranking sheets and interviews (level 4) to ensure that these data actually supported the identified themes. A review of these themes occurred to develop explanations, such as why more participants ranked one scenario as most ideal over the others. The researcher then compared each explanation to determine any relationships that existed between them (level 5). Lastly, through comparison of every component of these data gathered during each interview session, at level 6 the researcher was able to "develop a theory, more or less inductively ... and connect them" (Boeije, 2002, p.393).

\section{Credibility of the Study}

Triangulation (Merriam, 1998; Miller \& Dingwall, 1997; Patton, 2002; Stake, $1995)$ is used to increase confidence in the interpretation and also to establish credibility. This strategy was utilized to enhance validity because, as Miller and Dingwall (1997) point out, "replication of the findings by different methods minimizes the 
possibility that the findings may be the result of particular measurement biases." (p. 38). Maintenance of a research journal during data collection allowed the researcher to keep an "audit trail". Within this journal, the researcher kept interview notes recorded during each interview session. It was also used to document and organize questions, personal reflections, problems, issues, and assumptions (Merriam and associates, 2002, p. 27). This process, known as reflexivity, was important because it allowed the researcher to see how any notes recorded deviated from her initial expectations as well as any personal bias that may have existed, changes that needed to be made to the research design, and most importantly, any themes that arose from these data (Bogdan \& Biklen, 2007; Stake, 1995; Wiersma \& Jurs, 2005). Lastly, triangulation of multiple data sources (rankings and anecdotal notes from participants, and interview data) allowed the researcher to present findings that were void of any discrepancies.

In qualitative research, "providing rich, thick description is a major strategy to ensure for external validity or generalizability in the qualitative sense" (Merriam and associates, 2002, p. 29). A determinate of external validity can be "...left to those who read the report of the study", but the researcher must take proper steps to ensure that the research is "very well documented...so that contexts, subjects...can be understood with no confusion or ambiguity” (p. 216). By keeping careful documentation and presenting these data in a concise manner so that transferability of the study results is apparent, the researcher allows the reader to serve as an external reviewer.

\section{Summary}

This study examined the perspectives of pre-service students in a teacher education program in special education about characteristics of student diversity 
considered when selecting a teaching position. It sought to identify which characteristics should be present or absent in order for a position to be considered "ideal". Further, it identified the types of characteristics that may have influenced participants' choice of an initial teaching position. Data were collected through hypothetical teaching positions rankings, anecdotal writings, and face-to-face interviews and then analyzed to discover consistent themes in participant responses. The end goal in qualitative research is to construct a piece of work that is richly descriptive (Merriam and associates, 2002). As a representation of such a product, the researcher organized coded data patterns, themes, and a representative sample of direct quotations in table format to present the results. 


\section{Chapter Four}

\section{Results}

The purpose of this chapter is to report all data collected from eighteen (18) preservice students in special education who were interviewed in their final semester of a teacher education program. Table 4.1, a comparison of all characteristics, is included to show the hypothetical teaching positions developed for the interview sessions and the characteristics present in each as an introduction to the analysis.

Table 4.1

Hypothetical teaching positions and characteristics present in each

\begin{tabular}{|c|c|c|c|c|c|c|}
\hline School & Area & Race & SES & Disability & Performance & Salary \\
\hline Amherst & Suburban & $\begin{array}{l}\text { Predominately } \\
\text { White }\end{array}$ & $\begin{array}{l}18 \% \\
\text { high }\end{array}$ & $38 \%$ & $\begin{array}{l}\text { One of top in } \\
\text { area }\end{array}$ & $\$ 46,678$ \\
\hline Destiny & Rural & $\begin{array}{l}\text { Very racially } \\
\text { diverse }\end{array}$ & $\begin{array}{l}79 \% \\
\text { Low }\end{array}$ & $36 \%$ & $\begin{array}{l}\text { Barely met } \\
\text { AYP }\end{array}$ & $\$ 48,690$ \\
\hline $\begin{array}{l}\text { South } \\
\text { Park }\end{array}$ & Rural & $\begin{array}{l}\text { White Black } \\
\text { Hispanic }\end{array}$ & Low & $\begin{array}{l}\text { Full } \\
\text { inclusion }\end{array}$ & $\begin{array}{l}\text { One of few that } \\
\text { met in district }\end{array}$ & $\$ 40,980$ \\
\hline $\begin{array}{l}\text { Chestnut } \\
\text { Grove }\end{array}$ & Urban & $\begin{array}{l}\text { Predominately } \\
\text { White Black }\end{array}$ & $\begin{array}{l}30 \% \\
\text { Upper } \\
\text { middle }\end{array}$ & $\begin{array}{l}\text { Included } \\
\text { for majority } \\
\text { of day }\end{array}$ & $\begin{array}{l}\text { One of areas } \\
\text { top }\end{array}$ & $\$ 40 \mathrm{~K}$ \\
\hline Keystone & Suburban & Majority White & $\begin{array}{l}<10 \% \\
\text { wealthy }\end{array}$ & $14 \%$ & Lower end & $\$ 39 K$ \\
\hline Milvale & Inner city & $\begin{array}{l}\text { One of most } \\
\text { racially\& } \\
\text { culturally } \\
\text { diverse }\end{array}$ & $\begin{array}{l}40 \% \\
\text { Working } \\
\text { class }\end{array}$ & $20 \%$ & $\begin{array}{l}\text { Did not meet } \\
\text { AYP }\end{array}$ & $\$ 50,585$ \\
\hline
\end{tabular}

At the beginning of analysis, participants were linked to a number for reference and to ensure confidentiality as their responses are discussed. That information, as reported on the demographic information sheet, is included in Table 4.2. A review of the research questions are then provided followed by the results of the analysis. The interview data were analyzed using a data analysis map (Harry, Sturges, and Klingner, 
2005) as presented in Chapter Three. The analysis is presented in three sections in order to address not only the research questions but the additional data collected to determine any additional factors that could have affected participants' rankings of the hypothetical teaching positions. First, a summary of actual data from the ranking of hypothetical teaching positions is presented to answer research question \#1. Secondly, a summary of the factors reported during the follow-up interview sessions is presented to partially answer research question \#2, moving through the first four levels of the data analysis map. Lastly, a summary of the analysis of additional data collected in the interview sessions is presented to further address research question \#2 with specific focus on the last two levels of the data analysis map.

Table 4.2

Participant Demographics ( $n=18)$

\begin{tabular}{|c|c|c|}
\hline $\begin{array}{c}\text { Participant \# } \\
\& \\
\text { Gender }\end{array}$ & Hometown/city & Area \\
\hline 1. $\mathrm{F}$ & Cameron & Rural \\
\hline 2. $\mathrm{F}$ & Morgantown & -------- \\
\hline 3. $\mathrm{M}$ & Pitt 1 & Suburb \\
\hline 4. M & Pitt 2 & Suburb \\
\hline 5. F & Pitt 3 & Suburb \\
\hline 6. $\mathrm{F}$ & Pennsylvania & Rural \\
\hline 7. $\mathrm{F}$ & Baltimore & Urban/ suburb \\
\hline 8. $\mathrm{F}$ & Williamsville, NY & Suburb \\
\hline 9. $\mathrm{F}$ & Bridgeport & Suburb \\
\hline 10. $\mathrm{F}$ & Parkersburg1 & Urban \\
\hline 11. M & Parkersburg2 & Suburb \\
\hline 12. $\mathrm{F}$ & Parkersburg3 & Rural \\
\hline 13. $\mathrm{F}$ & Wellsburg & Suburb \\
\hline 14. $\mathrm{F}$ & Huntington & Urban \\
\hline 15. $\mathrm{F}$ & Charleston & Suburb \\
\hline 16. $\mathrm{F}$ & Cranberry Township, PA & Suburb \\
\hline 17. $\mathrm{F}$ & Sterling, VA & Suburb \\
\hline 18. $\mathrm{F}$ & Elkins/Bel Air, MD & Rural/ suburb \\
\hline
\end{tabular}




\section{Research Questions}

RQ1: What types of hypothetical teaching positions do pre-service students in special education choose based upon the presence or absence of specific characteristics associated with student diversity, namely race, class, or disability?

\section{Position chosen most frequently as most ideal.}

Because data analysis often begins during the data collection phase, a pattern of which hypothetical teaching position was being chosen over the others began to emerge at the end of the first phase of data collection. Visual observation of the actual rankings was used to begin answering the first research question in order to determine which hypothetical teaching position was ranked as the participants' most ideal, least ideal, etc. The number of participants that chose each hypothetical teaching position as most and least ideal is reported in Table 4.3. Once determination was made regarding which position was chosen as most and, conversely, as least ideal, further investigation into those two positions occurred to identify which characteristics were present (or absent) in each of those hypothetical positions.

\section{Table 4.3}

Summary of hypothetical teaching position rankings

\begin{tabular}{|l|c|l|c|}
\hline $\begin{array}{c}\text { Position chosen } \\
\text { as MOST ideal }\end{array}$ & $\begin{array}{c}\text { Number } \\
\text { of participants }\end{array}$ & $\begin{array}{c}\text { Position chosen } \\
\text { as LEAST ideal }\end{array}$ & $\begin{array}{c}\text { Number } \\
\text { of participants }\end{array}$ \\
\hline Amherst Peace & $8 / 18$ & Keystone & $6 / 18$ \\
\hline Destiny & $4 / 18$ & Milvale & $3 / 18$ \\
\hline South Park & $4 / 18$ & South Park & $3 / 18$ \\
\hline Chestnut Grove & $1 / 18$ & Chestnut Grove & $3 / 18$ \\
\hline Keystone & $1 / 18$ & Destiny & $2 / 18$ \\
\hline \multirow{2}{*}{} & Amherst Peace & $1 / 18$ \\
\hline
\end{tabular}


Table 4.4 is a direct comparison of the characteristics present in the most chosen hypothetical teaching positions. Amherst Peace was chosen as most ideal by eight (8) of the participants, and Keystone was chosen by six (6) participants as the least ideal. Based upon the characteristics of Amherst Peace, it could be deduced that the majority of the participants were more drawn to wealthy suburban areas where the population had little to no racial diversity. However, specific comments made about this choice as most ideal referenced the similarity of its characteristics to the school and/or areas where specific participants grew up. For example, participants \#3, 5, 7, and 8 all indicated that they chose Amherst Peace as most ideal because "it sounds a lot like the area I grew up in..." or that it was "most similar to where I went to school..." The first two of these participants were from the Pittsburgh, PA area. Participant \#7, from Baltimore, MD, stated that this position "reminded me most of the community where I came from" while the participant from Williamsville, NY simply stated that it "reminded me the most of my home...school I went to and ideally the school I would like to go back to".

\section{Table 4.4}

Comparison of hypothetical teaching positions chosen as most and least ideal

\begin{tabular}{|c|c|c|c|c|c|c|}
\hline School & Area & Race & SES & Disability & Performance & Salary \\
\hline $\begin{array}{l}\text { Amherst } \\
\text { Peace } \\
\text { (most) }\end{array}$ & Suburban & $\begin{array}{l}\text { Predominately } \\
\text { White }\end{array}$ & $\begin{array}{l}\text { High SES } \\
18 \% \\
\text { receiving } \\
\text { free/reduced }\end{array}$ & $38 \%$ & $\begin{array}{l}\text { One of top } \\
\text { performing } \\
\text { schools in } \\
\text { metropolitan } \\
\text { area }\end{array}$ & $\$ 46,678$ \\
\hline $\begin{array}{l}\text { Keystone } \\
\text { (least) }\end{array}$ & Suburban & Majority White & $\begin{array}{l}\text { Wealthy } \\
<10 \% \\
\text { receiving } \\
\text { free/reduced }\end{array}$ & $14 \%$ & $\begin{array}{l}\text { Lower end of } \\
\text { performance } \\
\text { scale }\end{array}$ & $\$ 39 \mathrm{~K}$ \\
\hline
\end{tabular}




\section{Position chosen most frequently as least ideal.}

Although many of these same characteristics were present in Keystone, participants reported that they chose this as their least ideal because of the low percentage of special education students, low salary, or because of the lack of diversity. Participant \#3 from Pittsburgh, PA felt that she “... wouldn't be able to help as many kids if there were only $14 \%$ ". Similarly, the participant from Baltimore, MD discussed the low special education population and stated that since it is "...only $14 \%$...as a special educator I don't know if that would be very helpful to me". There were two respondents who indicated that they chose this position as least ideal because of salary, but recognized that those who go into teaching are not in it for the money but one went so far as to state that it "...does make a difference in your decision." The discussions surrounding the characteristics of diversity in this particular position produced such comments as "Really high SES...really wealthy area...majority of population was white and only $10 \%$ was receiving free and reduced lunch...not what l'm looking for." A participant from one of the most racially diverse areas of WV remarked, "Wealthiest school and no diversity basically... don't know if I could relate....not exactly what I came from... don't think I would make as much of a difference.

Interestingly, only one participant chose Keystone as the most ideal teaching position and only one chose Amherst Peace as the least ideal. This phenomenon caused a more in-depth analysis to occur in order to determine the reasoning each participant chose the positions that they did since their selections were the opposite of the most chosen in each respective case. Those factors were compared and contrasted and will be discussed later in this chapter. 


\section{Discussion of other positions chosen as most ideal.}

Both Destiny and South Park were chosen by four (4) participants as the most ideal. Similar characteristics in both positions are that they are located in a rural area and the student population is described as racially diverse. Those choosing Destiny indicated their reasoning as being either because of the diversity or the salary. The two participants from the more diverse areas of WV (Huntington and Charleston) both commented on the diversity of the position while the two who indicated salary were from more prominent areas of the country (Cranberry Township, PA and Sterling, VA). A direct relationship between background experiences and choices can be seen from the choices made by these four participants. Further supporting this theory is the fact that of the 18 participants, not one chose Milvale, which specifically stated it was inner-city, as an ideal position.

Even though three (3) participants described their home city as urban (Baltimore, Parkersburg, and Huntington), none described the area where they grew up as being inner city. There were, however, three (3) participants who chose Milvale as the least ideal. Participant \#8 from Williamsville, NY noticed right away that the position included the phrase inner-city and said it was "first thing that I didn't like..." as did Participant \#9, who said that being from Bridgeport, WV she is “...intimidated by inner city just by driving and being there." A participant indicating that she grew up in rural Pennsylvania said that she felt that she "...would be eaten alive..." because she "...went to a really rural high school....taught in Preston County..." One statement directly supports the notion that background experiences impact choices. Participant \#8 further described her reasons for choosing Milvale as her least ideal school citing that since she was "...from the suburb...not had any experience in the inner city. Even with the program 
here....in rural area...never had the experience". There were others who simply described the phrase inner-city as "intimidating" and stated that they were "scared" or "afraid". One participant even stated that "even though this was the highest salary... [it] didn't even matter". Regarding the other positions chosen, South Park was the only position that stated full inclusion, which some participants (4/18) [Participants $\# 9,10,11,18]$ preferred while others $(3 / 18)$ [Participants \#2,16,17] avoided it for that particular reason and ranked it as their least ideal. Chestnut Grove was also chosen by three (3) of the participants as the least ideal, which stated "included for majority of the day".

RQ2: What factors do pre-service students in special education report as influencing their choices when selecting an ideal hypothetical teaching position?

In order to understand the reasoning behind the types of teaching positions that participants deem as ideal, it was necessary to ask follow-up questions not only pertaining specifically to their actual rankings but also regarding their backgrounds, their descriptions of an ideal position, experiences in the program, and anything else that may affect their decisions in selecting an initial teaching position upon graduation. Identifying specific characteristics that need to be present in order for participants to choose a position as ideal will provide insight into their perspectives on student diversity, namely race, class and disability. Data from follow-up interviews were analyzed to uncover what factors participants reported as affecting their choices of a hypothetical teaching position. These data were compared with actual markings and anecdotal notes written on the ranking sheets by participants. In Table 4.5, the most important factors that participants reported as considered in ranking their most ideal 
position are listed along with the number of participants who reported it and the statements made about that factor.

Table 4.5

Most important factor considered in ranking ideal teaching position

\begin{tabular}{|c|c|l|}
\hline $\begin{array}{c}\text { Most Important } \\
\text { Factor Considered }\end{array}$ & $\begin{array}{c}\text { Number of } \\
\text { Participants }\end{array}$ & \multicolumn{1}{c|}{ Statements recorded } \\
\hline $\begin{array}{c}\text { Context/location/area/ } \\
\text { community/ } \\
\text { setting/environment }\end{array}$ & $7 / 18$ & $\begin{array}{l}\text { "I prefer suburban over the rural" } \\
\text { "I don't like the city at all" } \\
\text { "ideally would like the suburban area" } \\
\text { "if I was comfortable" } \\
\text { "was looking more at urban" }\end{array}$ \\
\hline $\begin{array}{c}\text { Salary } \\
\text { sercentage of } \\
\text { students in }\end{array}$ & $2 / 18$ & $\begin{array}{l}\text { "that is first thing I look at" } \\
\text { "first thing that pops up to me" }\end{array}$ \\
\hline $\begin{array}{c}\text { If school was ranked } \\
\text { high/ } \\
\text { met AYP }\end{array}$ & $1 / 18$ & $\begin{array}{l}\text { "that is my passion" } \\
\text { or reach out, to serve" }\end{array}$ \\
\hline $\begin{array}{c}\text { Race/SES } \\
\text { or barely making AYP" }\end{array}$ & $1 / 18$ & $\begin{array}{l}\text { "I liked the experience of what they brought } \\
\text { into the school with diversity" }\end{array}$ \\
\hline $\begin{array}{c}\text { Diversity - didn't want } \\
\text { top income level }\end{array}$ & $1 / 18$ & "like a range of students to work with" \\
\hline $\begin{array}{c}\text { Need } \\
\text { \% }\end{array}$ & $1 / 18$ & $\begin{array}{l}\text { "want to go somewhere I can see that } \\
\text { change.... where this is a place where maybe } \\
\text { they don't really need me as much" }\end{array}$ \\
\hline $\begin{array}{c}\text { Free/reduced lunch } \\
\text { "goes with Title 1 and I want to work in a Title } \\
\text { 1 school" }\end{array}$ \\
\hline
\end{tabular}

\section{Race, Class, and Disability}

Participants were asked specifically about their consideration of the student diversity characteristics of race, class and disability. Overwhelmingly, participants reported that they did not consider race and those who did, were actually looking for 
more racial diversity. Of the eighteen (18) participants, ten (10)reported that racial diversity characteristics did not factor into their rankings with such statements as it "didn't matter" or that they "didn't notice" or that they "didn't consider" racial diversity in their rankings. There were five (5) participants who reported that they considered the characteristic of race and "would rather it be diverse" or that they are "pretty comfortable with diversity in the sense of race" and that they "prefer urban, suburban, more diverse...think it is a really great thing". There was one participant who reported that they looked at race and that it was the most important factor. Out of the three participants reporting that they considered and avoided race while ranking the positions, there was one participant who clearly didn't allow it to deter selection of the most ideal position as the position selected explicitly stated that it was racially diverse. While another stated that they "tried not to pay attention to it..." but that it "plays into diversity" in terms of avoiding certain positions.

The responses from participants pertaining to class were much more varied. There were those who reported that they didn't consider said that they "don't mind if it's low" or that they "never cared about either [high or low]...been at both". More interestingly was that there were five (5) of the participants who reported that they actually preferred low SES and five (5) others who reported avoiding it. One participant in particular reported that a low percentage of free/reduced would be "odd" and that she didn't know if she would "fit in....talking to students who get everything that they want". Other statements from those who reported a preference for low SES were:

"...looked at race then SES...most important factor"

"...free/reduced goes with Title 1 and I want to work in a Title 1 school"

"I know kids in poverty are in SPED so those are two things that I looked for" "...doesn't really matter.....prefer low SES" 
Reasons for avoiding the low SES included all of the "stories heard" about schools in low SES areas and that schools in higher SES areas get more funding and thus resources would be more readily available.

One participant who preferred higher SES schools said that from experience in low SES communities, there is a "lack of involvement/interest" but in higher SES communities the "parents are there every single day". More statements regarding the parents or the home life were also made with such comments as a "big thing [is]...parents [in low SES communities] could be more helpful" while another said that they "wouldn't want $50 \%$ of school receiving free/reduced lunch..." because "meals are missed at home [and] students come late then they have to get meals and educational time is affected". There were, however, two (2) who expressed a desire to teach somewhere in the middle, reporting their preference as "not the top of the income" and the desire to "stick to middle to lower". Consideration of this characteristic in an indirect way occurred as two (2) participants reported looking at the characteristic of class not to rank but to help get an idea of the school or because it "tied into the area". There was one participant who admitted a lack of experience with low SES and thus, would "not be comfortable".

When asked about disability characteristics and if they were considered while ranking the positions, participants reported that they didn't consider it or "didn't even look". Others reported that because they are in special education [major] and that's a "passion", they actually would prefer more and that it was "one of the first things looked at". Statements reported included wanting to be somewhere with a "relatively high percentage of students identified". One participant reported that they used the disability 
characteristic in ranking because of a preference for collaboration and stated that "where students are placed would influence my decision". A blanket statement made by one participant summarized her consideration of the characteristics. She stated that "The student population being whatever it may be doesn't matter to me...a kid is a kid".

The purpose of the follow-up questions was to gain additional data that would be used to compare with participants' responses to pointed questions regarding the actual rankings of the six hypothetical teaching positions. For example, participants ranked the positions from their most ideal to their least ideal. They were asked probing questions about their reasoning behind the rankings as well as to describe factors that influenced their choices and how they considered specific characteristics present in each position. During the follow-up portion of the interview session, each participant was asked to describe their ideal teaching position. These data were compared to the characteristics present in the position ranked as ideal by each participant and will be referred to as descriptive data used to help in identification of themes later in this chapter.

\section{Data Analysis Map}

\section{Levels 1 \& 2: Open codes and conceptual categories.}

In the follow-up interview sessions, participants reported and discussed many other factors as having affected their decisions to rank the teaching positions as they did, addressing RQ2. In Chapter 3, discussion of the use of a data analysis map to analyze these factors in order to find open codes, categories, themes, and ultimately theory occurred (see Chapter 3). To move through the map, it was necessary to look at data reported by participants besides reasons for selecting the most and least ideal choice and consideration of the student diversity characteristics of race, class, and disability; 
therefore, several other factors having influence over participants' choices were reviewed in order to see what emerged for level 1 of the map. All of the key points made by the participants when describing those factors were developed into a list of open codes found in Table 4.5. Some of the codes reported were context, location, area, setting, disability, school performance, comfort level, experience/training, and clinical hours. After careful consideration and review of all the list of codes, seven (7) conceptual categories were constructed based upon the commonalities present in the list (see Table 4.6, p.60). There were some codes, for example, like diversity and experience that fit into two different categories based upon the context in which they were used.

\section{Level 3 \& 4: Development and testing of themes.}

Triangulation, review of the multiple data sources identified in Chapter 3, occurred throughout the analysis. In reviewing all of the descriptive data from the ranking sheets, the anecdotal markings on them, the interview transcripts and researcher notes recorded in the research journal, certain themes appeared to emerge naturally. Thematic analysis (Harry, Sturges, and Klingner, 2005) was the next step in the data analysis phase and the identified conceptual categories were reviewed for determination of links between them in an effort to develop actual themes. In reviewing the broad conceptual categories identified in level 2, the researcher was able to make linkages amongst them through the process of sorting and resorting the data cards.

Initially, 'characteristics of diversity' was identified and three different themes were developed pertaining to this broad category. In order to test the identified themes (Level 4), a more thorough review and comparison of all data collected from the multiple 
sources revealed that these three themes could be clustered into only two separate themes: 1) Influences of Family and Community on Beliefs and 2) Influences of Preparation Program on Beliefs. By staying grounded in the data, the researcher was able to inductively and deductively work through all data sources in order to advance to the next level.

Table 4.6

Conceptual Categories and Open Codes.

\begin{tabular}{|l|l|}
\hline Categories & Open Codes \\
\hline Community: & $\begin{array}{l}\text { Context, location, area, community, setting, environment } \\
\text { Inner-city } \\
\text { Rural } \\
\text { Suburban } \\
\text { Diversity } \\
\text { Salary }\end{array}$ \\
\hline Special Education: & $\begin{array}{l}\text { Disability } \\
\text { Percentage of students in special education } \\
\text { Placement of students identified } \\
\text { Need } \\
\text { Collaboration/co-teaching } \\
\text { Full inclusion } \\
\text { Diversity -learning styles }\end{array}$ \\
\hline School performance/ranking, meeting AYP \\
\hline Academics: & Racial/cultural background of students, ESL, religion \\
\hline Diversity: & $\begin{array}{l}\text { Socio-economic status } \\
\text { Free/reduced lunch percentage } \\
\text { Title I }\end{array}$ \\
\hline Class: & $\begin{array}{l}\text { Familiarity } \\
\text { Comfort level } \\
\text { Stories heard (about certain populations) } \\
\text { Lack of exposure/experience/training }\end{array}$ \\
\hline Background & $\begin{array}{l}\text { Clinical experience - number of hours - over 1000 } \\
\text { Lack of exposure/experience/training } \\
\text { Courses - Assessment, Methods, Instructors }\end{array}$ \\
\hline Experiences: & \\
\hline Program Experience & \\
\hline
\end{tabular}

A more in-depth analysis of the aforementioned data sources was needed to discern, or test, what themes were actually supported by the data. Throughout each 
interview session, a method of member checking was used to ensure accuracy in the participants' responses and assure credibility. This was done through a periodic review of participant responses as the researcher moved through the interview protocol.

Further review of the interview transcripts occurred to determine the extent to which the data actually supported the identified themes.

6. Theory: Background experiences strongly influence perceptions of pre-service students in special education, namely when it comes to consideration of student diversity characteristics such as race, class, and disability. Program experiences also affect perceptions but are secondary to those background experiences such as family, community, and educational experiences. Perceptions are evolving and influenced by many factors that work in accordance with one another during decision making processes.

\section{Interrelating the explanations: $\longleftrightarrow$ Influences of Family $\longleftrightarrow$ Influences of Community (including K-12 experience) $\longleftrightarrow$ Influences of Preparation Program (including coursework and internship)}

4. Testing the themes:

$$
\begin{aligned}
& \text { Influences of Family \& } \triangle \text { Influences of Preparation } \\
& \text { Community on Beliefs Program on Beliefs }
\end{aligned}
$$

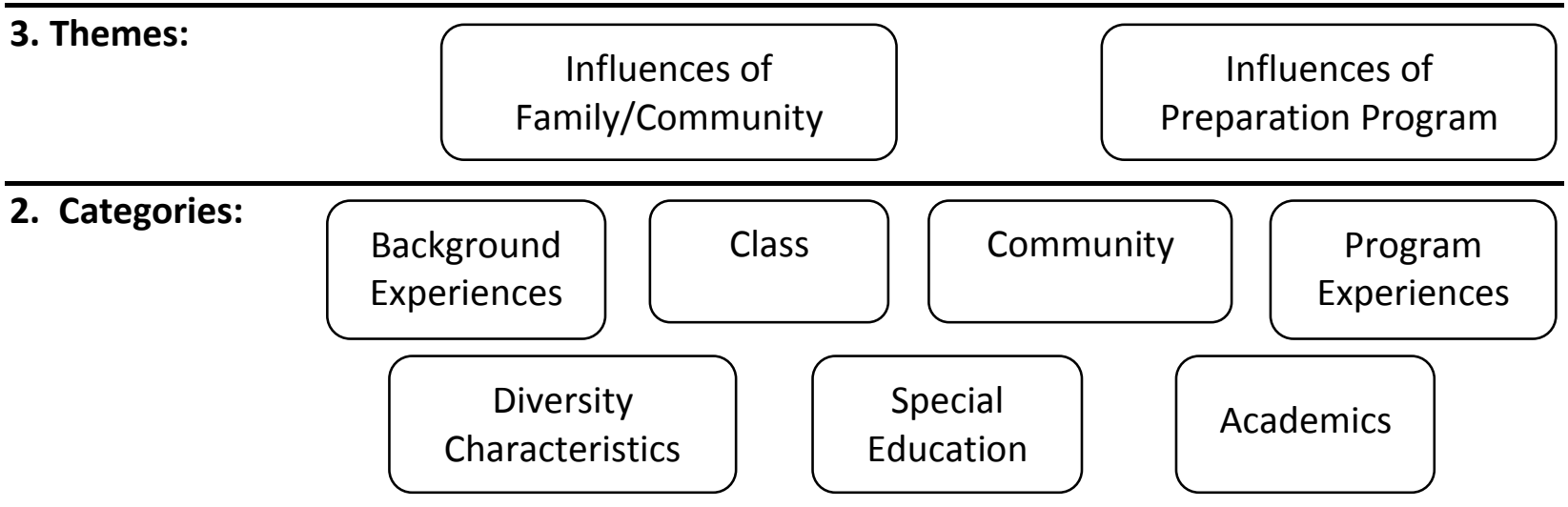

1. Open Codes:

See Table 4.6

\section{Figure 4.1. Data Analysis Map}

The abundant amount of data collected during this study made this step of testing the themes a lengthy one. Interview transcripts were read and re-read for 
assurance that all units of data were recorded and accounted for in the first two levels. Secondly, the transcripts were compared based upon participants' rankings, demographic information, and specific statements recorded in an effort to ensure that the identified themes were accurate in their ability to represent all data collected during the course of this study. Testing of the data required a thorough investigation into the data for evidence of the identified themes and thus, the theme 'Program Preparedness', which referred to all data describing how prepared the participants felt as a result of their program was changed to 'Perceptions of Program Preparedness' in order to capture the effect that participants' beliefs about their program and how well it prepared them had on the study data as well as their beliefs. This theme was again altered for clarity purposes to 'Influences of Preparation Program on Beliefs'. Similarly, 'Influences of Family/Community' was changed to 'Influences of Family and Community on Beliefs' in order to show that participants' responses regarding specific experiences had some effect on their personal belief systems. It should be noted here that community includes the individuals and experiences present such as those gained during a K-12 education. Because in level 5 , these themes become explanations, this investigation occurred until assurance was gained that all data can be clustered into the themes identified. Before moving into the last two levels of analysis, a discussion of the additional data collected during the interview must occur in order to provide more insight into research question \#2 and thus, develop a theory.

\section{A more in-depth look at the factors that affect selection of teaching positions}

In addition to the probes regarding the actual rankings, in the second part of the interview session, participants were asked a series of more general follow-up questions. 
The purpose was an attempt to allow data to emerge relative to exactly what each participant thinks about generalities such as their choice to enter the teaching field, characteristics present in their personal ideal teaching position and general questions about the teacher education program. On the demographic cover sheet provided during the first phase of the data collection, participants were asked to identify the factors that affected their decision to enter the teaching field as well as their decision to gain an additional endorsement in special education. Participants were asked these exact same questions again during the follow-up portion of the interview session and 18/18 participants reported similar, if not exactly the same responses both times asked. Factors reported consisted of parental/family influence, past experiences working with individuals with disabilities, passion for teaching, love for children, lifelong career goal, and former teachers as affecting their choice to not only enter the teaching profession but to become a special education teacher. (See Appendix B)

When asked to describe the single most important factor used in selecting a teaching position in general, along with any other relevant factors that could affect their decision to accept a teaching position, participants reported a variety of responses. Many of the responses were similar to those provided when participants were asked earlier in the interview session to explain their rankings from the initial interview phase (See Table 4.5). Overall, the analysis found such responses as the location, the special education population served, and the specific nature of the position (full time, collaboration, and community environment) were reported most often. Other factors of importance were communication, salary, and type and level of support provided. Table 
4.7 lists all factors reported as most important as well as considered during the interview sessions.

\section{Descriptions of an ideal teaching position}

In order to fully understand the participants' rankings and data reported regarding those rankings of an ideal hypothetical teaching position, participants were asked to describe their own ideal teaching position and how that ideal has or has not changed as a result of their experiences in the teacher education program. Out of eighteen (18) participants, seven (7) reported that their ideal did not change, nine (9) reported a positive change, and two (2) reported that their ideal changed as a result of their experience because they now know what they do NOT want. The descriptions of an ideal teaching position did not appear to follow any type of pattern, although of the eight (8) who said that their ideal changed, two (2) wanted a diverse setting, two (2) wanted general education, and two (2) said that general or special education would be ideal.

More interestingly, is that the two (2) participants who reported that their ideal changed because of negative experiences both indicated that they wanted diversity to exist within that position. As noted, participants' descriptions of the characteristics present were probably the most varied data collected. While some provided specifics on the exact grade level they would like to teach others described the level (elementary/secondary) or the setting preferred (general/special education and inclusion/self-contained). There were those who identified a specific location (Maryland/Morgantown) and others who chose to describe either the area (suburban/urban/community involvement) or whether the school was performing well. Most notably is the fact that diversity was mentioned in several of the descriptions. 


\section{Teacher Education Program Experiences and Perceptions}

Additionally, the researcher thought it important to discover the experiences that participants felt prepared them (or not) to teach in today's diverse classrooms. The data were placed into three separate categories. They reported that clinical experience/number of hours, coursework, and research into practice experience all prepared them to deal with the changing classrooms of today. Similarly, the participants reported that coursework did not have a bearing on their experiences or that it did not help in their preparation process. Specifically, it was reported that strategies were lacking, the assessment course was not helpful, and that the science methods course experience was not "varied enough".

In order to fully analyze the data gathered in this study, it was necessary to inquire about participants' perceptions about the teacher education program (strengths, weaknesses, and suggestions). From these responses, it is apparent that participants overwhelmingly credit their clinical experience as the key to their success in this program and thus, what made them ready for today's classrooms.

It can be seen that out of the 18 participants, 12 used the term experience, 7 used time/hours, and 6 discussed the variety of the placements - grade levels, different schools, and different classrooms when reporting strengths of the program. There were, however, some weaknesses of the program reported. They included issues with the course (sequence, repetition, and content), communication/collaboration between instructors, special education and the program, and between the faculty and the students. Some also reported issues with their actual internship placement. Lastly, participants were asked to offer suggestions for improving the program. Although the responses were varied, they could be categorized into just a few topics: better 
communication/collaboration, additional and relevant coursework and experiences to include more special education and racial/cultural diversity experience, and improvement on the sequence of program components.

\section{Data Analysis Map}

\section{Level 5: Interrelating the explanations.}

At this level, the explanations formulated in level 4 (see p.60) were examined to determine how they compare and contradict one another in order to find out if they in fact relate to one another and what that relationship may be. Coming up with explanations for why participants reported the factors that they did was not an easy task. The additional data discussed in the above section further informed the relationships and thus, it was concluded that the explanations, Influences of Family and Community on Beliefs and Influences of Preparation Program on Beliefs, are very similar.

When looking at how belief systems are derived, it is important to acknowledge that background experiences play a significant role. For example, perceptions of education, racial and class differences, as well as certain geographical areas are all developed from family/community influences and these perceptions continue to have an effect on how information gained during program preparation is processed. A question here may be exactly how hard is it to change what has been ingrained for $18+$ years? Perhaps additional belief systems can be developed or existing ones may even be changed based upon experiences gained within an intense educational process such as a teacher preparation program internship. In the map (see Figure 4.1 p. 61), horizontal 
arrows are used to show that neither explanation can stand alone, and thus, that they are interrelated.

The influences that family and community had on participants had to affect how the experiences gained from the program were perceived and thus the impact or influence that these experiences had on participants' beliefs. In fact, Levin and $\mathrm{He}$ (2008) discussed the beliefs of teacher candidates and claim that identity development is related to beliefs and that this identity is "everchanging" (p.56). To further solidify the discussion of this relationship, two separate comparisons were made of specific participants' responses to show how perceptions differ and how those perceptions may, in fact, affect one's beliefs. In the first example, the participants' responses who selected in opposition to the majority for their most and least ideal are provided. Amherst Peace was chosen by $8 / 18$ participants as their most ideal yet one participant chose it as their least. On a similar note, one participant chose Keystone as their most ideal, which was chosen by 6 participants as their least ideal position. It should be noted that, while giving their responses, both participants more so than any of the others stammered while they gave their responses; they provided the responses but without as much conviction as they did their other answers. They seemed to know exactly WHY they ranked their top and bottom choice but didn't seem as comfortable verbalizing it. The responses from participant \#3, who said she grew up in a rural area, and participant \#18, who said that she grew up in a rural area and then moved to a suburban area, support the notion that personal backgrounds affect choices. Both participants chose in opposition to the majority and explained their reasoning for doing so, both referencing their background and what they are most familiar and comfortable 
with. In her response to "Why did you rank Keystone as the most ideal position?", participant \#12 replied,

...because that is what I am most familiar with right now. The majority of the population white with fewer than $10 \%$ receiving free or reduced lunch and the school l've been in over the past three years has had fewer than $5 \%$ receiving free or reduced lunch. It is also in a suburban area which is an area I am familiar with. $14 \%$ has been identified as having special needs and the school I came from did not have many kids who had special needs so I picked that one probably because it was the one I was most familiar with. Money wasn't an issue.

Further supporting this notion, her response to "Why did you rank Destiny as the least ideal?" was, ...low SES. My school where I came from had very high SES, probably because that is what I am the least familiar with so I didn't want to venture out to the unfamiliar. Free or reduced lunch was $79 \%$ of the kids so that tells you that a lot of them comes from low SES. With my experience kids who come from low SES tend to have not such good study habits or work habits so you probably constantly have to be like redirecting them all the time. $36 \%$ needed special education. That wasn't an issue, the ones receiving special ed was not an issue. [It's] probably the low SES.

Participant \#18, responding to the question of "Why did you rank Amherst Peace as the least ideal?" stated, 
The only thing I can think of is it is a wealthy neighborhood, it was high socio economics, suburban. That is where I grew up; in a very wealthy suburban neighborhood in Maryland but my family is from rural West Virginia so I just want to go back.

In responding to her choice for most ideal, she reported, "I like the rural part of it. I like that they are meeting AYP. I like to co-teach if it is done properly. I like the full inclusion. I think that helps kids."

The second part of this discussion on the relationship between beliefs and choices pertains to the comparison of the three participants listing Parkersburg as their home city. Each categorized this area differently; one referred to it as urban, another rural, and the third referred to it as a suburban area. Table 4.11 lists these participant responses according to the way in which they categorized their area. Another factor of importance in this analysis is that the participant who categorized her home city as rural was the participant identified earlier in this discussion (participant \#3) who chose Keystone as the most ideal teaching position. Conversely, the participant who categorized their home city as an urban area chose Keystone as their least ideal. 
Table 4.7

Data comparison of three (3) participants from same city

\begin{tabular}{|l|l|l|l|l|}
\hline Home city & Area & $\begin{array}{l}\text { Most } \\
\text { ideal }\end{array}$ & $\begin{array}{l}\text { Least } \\
\text { ideal }\end{array}$ & Actual recordings on data sheet \\
\hline Parkersburg & Rural & Keystone & Destiny & $\begin{array}{l}\text { Underlined: Diversity characteristics - } \\
\text { race, class, disability + location (urban, } \\
\text { suburban, rural) + circled salary } \\
\text {--Starred inner-city on \#2 and underlined } \\
\text { performance on \#6 (low end of scale) }\end{array}$ \\
\hline Parkersburg & Suburban & S. Park & $\begin{array}{l}\text { Chestnut } \\
\text { Grove }\end{array}$ & $\begin{array}{l}\text { Underlined: Salary in all, (said that was } \\
\text { most important and first thing he looked } \\
\text { at) } \\
\text { Also underlined in one or two: disability, } \\
\text { performance (2), class }\end{array}$ \\
\hline Parkersburg & Urban & S. Park & Keystone & $\begin{array}{l}\text { Most: I am most interested in this school - } \\
\text { there is a "low-SES status" \& diverse } \\
\text { student w/full inclusion Like my PDS }: \text { \#6 } \\
\text {-l'm not 100\% sure about "rural" \#5 } \\
\text {-interested but nervous \#4 } \\
\text { Least: No - too many in the "wealthy" } \\
\text { category \#1 }\end{array}$ \\
\hline
\end{tabular}

\section{Level 6: Theory.}

After careful consideration and comparison of every single component of data gathered, theory was developed to further address research question \#2. As discussed throughout this chapter, numerous factors affect pre-service students in special educations' decision to teach in a specific setting. Whether they choose a position because it was close to home or where they already knew they wanted to live, because it paid the highest salary of all offers, or because the components of the position were aligned with their expectations of an ideal teaching position, the fact remains that there are influences in existence that factor into the decision making process. These influences do not exist in a vacuum and thus, work in accordance with one another when a decision, such as an initial teaching position, needs to be made. 
Background experiences, such as family, community, and K-12 education strongly influence not only who an individual becomes but what beliefs they may hold. In regards to teacher education, beliefs about certain student populations, school districts, geographical areas, and expected salaries, for example, may come directly from these aforementioned background experiences. When a student enters into a teacher education program, these beliefs come along with them but may or may not be changed by their experiences within that program. Factors such as coursework, instructors, and field experience allow those students the opportunity to expand their knowledge but also to adjust or completely alter their original beliefs. Levin and $\mathrm{He}$ (2008) assert that "teacher education programs can influence teacher candidates' beliefs..." (p.66). In this study, they determined that the sources, or influences, on these beliefs could be categorized into three categories: family background and $\mathrm{K}-12$ experiences, observations and teaching experiences, and teacher education coursework (p. 61). From this, the supposition can be made that numerous influences weigh in on the consideration and selection of an initial teaching position by pre-service students in special education as well as what that initial position should "look like". There is not one of these constructs that exists alone; they work in conjunction with one another as belief systems continue to develop.

\section{Conclusion}

This chapter has presented the findings of the study of how pre-service students in special education rank hypothetical teaching positions as well as what factors they report as affecting those rankings and selection of an ideal hypothetical teaching position. The findings were analyzed and presented in a linear fashion using a data analysis map to show how all data were considered. Since such an abundant amount 
of data was collected, the analysis began with a focus on answering the two research questions. Secondly, the additional data collected were analyzed and presented to show its importance in this study. Lastly, all data were considered, compared, contrasted, and developed into a theory. 


\section{Chapter Five}

\section{Discussion}

\section{Introduction}

This chapter is a discussion of the conclusions and recommendations gained from this research study. It begins with a brief introduction and statement of purpose followed by a restatement of each research question. Major findings for each research question will follow. A general discussion and conclusions will precede an attempt to relate these findings to previously discussed research. Next, implications for policy and practice will be discussed. Lastly, limitations of the study are discussed in order to present implications for the field and future research.

\section{Summary of Purpose}

The purpose of this study was to understand the specific characteristics of student diversity that participants look for or avoid when choosing hypothetical teaching positions in an attempt to determine what characteristics should be present or absent in a hypothetical teaching position for pre-service students to deem it an ideal teaching position. For the purposes of this study, student diversity was defined as individual differences in race, class, and disability. The study also explored whether a relationship exists between participants' perceptions of diversity and their choices of a hypothetical teaching position. Lastly, an examination was made into the factors that participants reported as affecting these choices.

The research questions guiding this study were:

1) What types of hypothetical teaching positions do pre-service students in special education choose based upon the presence or absence of specific characteristics associated with student diversity, namely race, class, or disability? 
2) What factors do pre-service students in special education report as influencing their choices when selecting an ideal hypothetical teaching position?

\section{Summary of Findings}

\section{Major findings based on research questions.}

RQ1: What types of hypothetical teaching positions do pre-service students in special education choose based upon the presence or absence of specific characteristics associated with student diversity, namely race, class, or disability?

Based upon the data from ranking sheets, it can be deduced that the majority of participants prefer a position located in a suburban area that is predominately white and where the school is a top performing one. Since nearly half, or $8 / 18$, of the participants ranked Amherst Peace as their most ideal teaching position, the data suggest that preservice teachers choose positions that have a relative number of students identified $(38 \%)$ and a population that is relatively wealthy (18\% free/reduced lunch and high SES). Their responses revealed that they do not choose positions based upon salary, as Amherst Peace had the third highest salary of the six positions listed.

Interestingly, during the follow-up interview sessions, there was an identified preference to teach in rural areas as well as in ones that were more racially diverse, which was contradictory to the expected results of this study. More intriguingly is the fact that when asked about consideration of race, most said that they didn't notice or actually preferred a diverse student population. This is in direct opposition to the position that, again, the majority of them chose as most ideal, which clearly stated that it was predominately white and suburban. Although there were a few who indicated that they would not mind teaching in an urban setting and a few more whose ideal would be 
in a rural setting, the data clearly support the notion that inner-city was not a consideration. Not one of the participants selected Milvale as their ideal position and this one described the area where the school was located as inner-city. A discussion regarding how uncomfortable a position of this nature would be took place in $50 \%$ of the interview sessions. The level of unfamiliarity with this type of setting and thus, the students within this setting was what drove the discussion. Even though the salary was the highest of all listed, this position still was not chosen as an ideal setting. In fact, one participant indicated that as much as a high salary was preferred, she was still not willing to teach in an inner city area.

Pertaining to disability, most preferred positions with high numbers of students identified special education and expressed how they ranked certain positions because they preferred a higher percentage of identified students. Participants reported that the reason that they are in a special education program is to teach special education students, except for one student who said that she wanted to become a better teacher all around and felt that the special education endorsement would allow her to be just that. Full inclusion was clearly stated in one of the positions and noticed by several participants; there were $4 / 18$ that chose this position as their most ideal. There was also a position that said that the students were "included for majority of the day", yet only one participant chose this position as their most ideal. The data suggest that there was a mix on consideration of this - some preferred it while others avoided the specific positions where it was mentioned because of it.

In terms of class, a surprise finding was that participants either preferred or avoided low SES (aside from the position that they ranked as most ideal, which was 
high SES). They discussed stereotypes associated with students that come from impoverished backgrounds and the surprise is that they used these stereotypes to make their selections. Data from the follow-up interviews on the factors influencing their choices support this notion.

RQ2: What factors do pre-service students in special education report as influencing their choices when selecting an ideal hypothetical teaching position?

Overall, background experiences such as family/community influences, $\mathrm{K}-12$ educational experience, and perceived ideas about specific characteristics of diversity played a major part in selections. There were instances when it was evident that stereotypes played a role in the selections. The researcher discovered that direct statements made during the interviews indicated that some participants allowed what they have heard (stereotypes) or their perceptions about certain characteristics of student diversity (race, urban/city, low SES, high SES) to affect their choices. Participant \#2, from Morgantown, explaining her reasoning for why she chose the position that explicitly stated it was 'inner-city' as her least ideal said “....maybe it's from stuff you hear in school in classes and different examples. I don't know if that would be the greatest first job for me." Two other participants who indicated the same city (Parkersburg) as their home city, yet one categorized it as rural and the other suburban also provided background for steering clear of the position that indicted it was 'innercity'. Participant \#11 stated, "You hear all these stories about inner city schools and you get so much money but it is so difficult to teach there and as a first year teacher I am not sure I could deal with it." On the other hand, Participant \#13, who categorized Parkersburg as rural, was clear on her feelings on certain characteristics. She 
remarked, "Kids who come from low SES tend to have not such good study habits or work habits so you probably constantly have to be like redirecting them all the time. $36 \%$ needed special education....wasn't an issue...probably the low SES." More interesting is the fact that she ranked the 'inner-city' position as her NEXT to least ideal. She explained, "Well with Millvale school, it is an inner city school district and that's scary to me...You just hear about it so probably the pay would be nice but I am not looking to get shot in school." She went on to comment on her least ideal choice, "...a lot of kids in special ed come from lower SES homes and I think that could be avoided if the parents would just be more helpful."

Secondly, clinical experience was a factor and appeared to have affected some positively and some negatively affecting how they chose the teaching positions as most ideal. There were experiences that allowed a few participants to know exactly what they would NOT want in a position, while others felt their internship experience was lacking and thus, they PREFERRED more diversity (race, class, disability). Surprisingly, the one factor that I thought would factor in most did not seem to have much effect on choices. The majority of participants reported that they either didn't notice racial diversity in the positions or that they did because they preferred more racial diversity in their ideal teaching position.

Responses regarding disability were similar in that they were training to become special education teachers and thus wanted to teach special education students indicating a preference for a higher percentage of students identified with some of the positions that they were provided to rank as most, least ideal, etc. 


\section{Discussion}

In this section, an attempt will be made to link all data with conclusions and therefore, provide rationale(s) for the recommendations provided for the field. Data were collected from 18 pre-service students in a special education teacher education program. The demographic data of the participants provided a backdrop for all analysis and a discussion regarding this study. All of the participants were white and all said that they grew up in middle class environments. As for the area in which they grew up, $12 / 18$ of the participants described their home cities as suburban, while $3 / 18$ depicted their home city as urban and 3/18 rural. One participant who provided Baltimore, MD as her home city explained that she lived in an urban area and then moved to a more suburban area of the city when she was older. There was another participant who discussed moving with her family, indicating that she grew up in rural WV and then moved to suburban Maryland (outside of Baltimore, MD). One participant who grew up in Morgantown, WV was unsure of how to describe the city and thus, she did not answer that portion of the demographic data sheet.

Unexpected findings of the study were the number of participants who stated that they had an actual preference for more diversity. They pointed out that they would prefer a higher percentage of students identified as having a disability. There were even a few who stated that they would prefer to teach students from low SES backgrounds. Perhaps the most surprising finding was that this particular population of pre-service students in special education actually identified the need for more racial diversity. Even if they discussed being more comfortable in another environment, a 
discussion still ensued regarding the need for more exposure to this particular aspect of diversity during their clinical experience in order to be an effective teacher.

Although there were no outright negative statements regarding diversity characteristics, there was one participant who highlighted the fact that she had no desire to teach students from low SES, pointing to the lack of exposure that existed in both her clinical experience and while she was growing up. As she finished her discussion of her level of unfamiliarity with this specific population, she stated that she just didn't want to "venture out to the unfamiliar".

\section{Conclusions}

Basis for this study grew out of years of interactions with pre-service teachers in a teacher education program and the experiences gained as a result of those interactions. It was believed that most participants would avoid specific areas of diversity, namely race, class, and disability, even though they are getting an endorsement in special education. This study examined the perspectives of one group of pre-service students in a teacher education program in special education about characteristics of student diversity considered when selecting a teaching position. Identifying the characteristics that should be present or absent in order for a position to be considered "ideal" was a main focus of this study as well as the types of characteristics and factors that influence participants' choice of an initial teaching position. Lastly, it attempted to discover if a need exists for pre-service students in special education to have more exposure to areas of diversity such as race, class, disability and the intersection of the three. 
The belief that specific areas of diversity would be avoided by this particular population of participants as they selected ideal teaching positions was unfounded. In fact, findings suggested that a need for MORE diversity as a whole was actually the case. In regards to race, data revealed that not only did participants not avoid the hypothetical teaching positions that included racial diversity, but many commented on the positions that included low percentages of racial diversity with such comments as it not being "real". As for class, many of the participants reported that they actually preferred to work with students from lower socio-economic status and in areas where the schools had high numbers of students with free/reduced lunch. There were a few, however, who reported that they would NOT want to work in these areas and provided reasons that stemmed from their own background experiences or something that they had "heard" about those students or areas. Disability was the diversity characteristic that was perhaps the most surprising finding was that all but one of the participants discussed the desire to work with students with special needs and even referred to that being the reason that they ranked the positions as they did as well as why they decided to get the additional endorsement. The one who said that she didn't want to be a special education teacher said that she decided to get the endorsement to make her an overall better teacher.

Not surprising were the factors reported by participants as to what affected their selections of hypothetical teaching positions as well as what they deem as an ideal position. Findings from the study suggested that the participants were very diverse in their descriptions of an ideal teaching position. Descriptions included specific areas, locations, settings, as well as school performance and the need for diversity (race, 
class, and disability) to be present. Factors reported as having influenced these descriptions were just as varied. Participants discussed such factors as where a school was located (urban/suburban/ rural and close to family/home city) and who it was serving (student diversity characteristics) as well as the exact case load of the position (full inclusion, specific disability category, and severity of population). The data also found that participants were as concerned with the actual work environment, i.e. administrators, other teachers, and overall tone of the environment - if everyone appeared to have the same position and promoted a positive work environment. There was a participant who reported that salary played a role in how she ranked the positions.

Data from RQ2 revealed that background experiences and beliefs/perceptions about those who are considered "different were significant factors that affected not only the ranking of the hypothetical teaching positions but also the descriptions provided of an ideal teaching position. Participant \#15 from Charleston, a place that others may characterize as more of an urban setting for the state of WV, explained her reasoning for ranking the positions as she did indicating, "I guess I am making my ideal school around where I came from. But I have to stay in Morgantown since I am married." Another participant (18) provided similar sentiments, I didn't really consider race. I was looking at it if I was to get a job now what would I take and since I know round about where I am going to be living, I just did it [ranked positions] to what was similar to that. I know I am not going to be in a diverse population. I wouldn't bother me at all, I just now that is not where I will be living. [on being married to someone from a rural area who already has a job 
there and what is her actual ideal position] ... if I wasn't married to a country boy...I would like to go back to Maryland.

Many participants discussed their "experiences" as having affected not only their thought processes but their actual rankings during data collection, pointing out the lack of experience during their preparation program as what kept them from selecting certain positions. For example, participant \#12, from Parkersburg, categorized her home city as rural and said she selected the position that she did as her most ideal, ...because that is what I am most familiar with right now. The majority of the population White with fewer than $10 \%$ receiving free or reduced lunch and the school l've been in over the past three years has had fewer than $5 \%$ receiving free or reduced lunch. It is also in a suburban area which is an area I am familiar with. $14 \%$ has been identified as having special needs and the school I came from did not have many kids who had special needs so I picked that one probably because it was the one I was the most familiar with.

She continued with an explanation on her least ideal position stating, "My school where I came from had very high SES, probably because that is what I am the least familiar with so I didn't want to venture out to the unfamiliar." Participant \#4, from Pittsburgh, PA, remarked, "...I am more comfortable with our experiences in the program working in a suburban or rural setting than... an urban setting..." Similarly, participant \#8, from a suburb in NY, explained that she was "...not from an area that has had a lot of diversity...haven't had a lot of experiences not saying I am not open to it. Personally, have never had a very diverse environment to work [in]." One of the most interesting responses came from participant \#9, from Bridgeport, who said, 
My number one said they had white, black, and Hispanic so that was a little diverse. My sixth was probably my most diverse and this is the one I put not so much for and that's what I said and it is not because of the kids, it's my lack of experience. It is just intimidating I guess since I haven't had that experience.

There were some study participants who discussed their background experiences from a more positive vantage point, highlighting the diverse environments that they grew up around. Participant \#7, from Baltimore, MD, responded, "My experiences as a student were great and as a teacher were really good so that definitely came into play. I really like where I am from, home." Also, a participant from Sterling, VA (17), stated, "I feel I am well prepared to take any job because where I went to school is a totally different environment than where I taught in so I have the experience so I am more prepared."

The following statements made by participants gave credence to their program experiences as having affected their choices in a positive fashion. Indicating her home city as (urban) Huntington, participant \#14 felt that her background experiences prior to the program affected her decisions. Regarding her clinical experience, she stated,

I think just me being at YYYYY Elementary School made me appreciate other cultures. I already was an open-minded person. I wasn't closed off to anything like that but after Huntington there is a mix of African Americans and Whites and stuff like that in the high school where I grew up but nothing like that nature like over 33 languages represented... being able to use that as a teaching tool...Taking that into another school like ZZZZZ Elementary School and showing it because you know you have that experience. 
Ultimately what is important is the fact that you want to be a teacher so you should want to teach ALL students. This was the sentiment expressed by a participant who grew up in a suburb of Pittsburgh (16). When asked about her most and least ideal teaching position, she responded,

In the school I am in right now, XXXXX Elementary school has some higher and lower where SSSSS Elementary is pretty low. So I have been in every situation growing up back home it [SES] is pretty high so I have seen every aspect of it so that doesn't really bother me at all in the classroom. It doesn't matter where you came from; you are there for the same reason.

Perhaps the most profound statement in support of this notion of experience having an effect on the decisions of pre-service students was made by participant 6 , who described her background experiences and how they affected her,

I am originally from Pittsburgh so if I would have stayed in Pittsburgh I might be more interested in something like that but I didn't. I moved to the middle of nowhere and ended up loving it and I taught in the middle of nowhere so I guess I can't leave my little bubble. My little comfort."

A sampling of the sentiments expressed by the majority of participants during data collection hav been presented. Thorough analysis allowed the researcher to gain insight into their perceptions/beliefs regarding specific populations and locations.

The findings of this study are consistent with studies done on teacher candidate beliefs and perceptions. Results provide useful information for teacher education programs in that determining the factors that pre-service students consider when selecting hypothetical teaching positions can offer some insight into perceptions of 
characteristics of student diversity held by pre-service students at this institution. Most recently, Watson (2001) conducted a study of 16 teachers, educated in a teacher education program at an urban institution examining their perceptions of the term urban. She found that participants' perceptions of how urban students actually were influenced their expectations of those same students. Levin and $\mathrm{He}$ (2008), in their discussions of Personal Practical Theories (PPT), pointed out beliefs of teacher candidates is a phenomenon that has been studied for years. By presenting a model in which teacher education program researchers can connect findings about teacher candidate beliefs with the sources of those beliefs, they opened up a new line of research into determining what teacher education programs can or cannot do to affect change to these beliefs. They maintain that programs should focus more on "...why we seem to have more influence on beliefs about instruction and less influence on beliefs about who teachers are" (p. 66).

As Green points out "in order to meet the needs of ...diverse students, special educators need to understand the importance of utilizing culturally and linguistically appropriate and relevant practices" (p.14). She continues with the important notion that both general and special education teachers should be prepared to teach students who are diverse. This is best accomplished by a look at the literature on beliefs and perspectives of pre-service teachers related to teaching students from diverse backgrounds. It should be noted that this literature addresses disability as an area of diversity as well. Pohan (1996) discusses diversity, pertaining to cultural diversity as well as diversity of others, which includes diversity in terms of "race, ethnicity, social class, gender, disability, language, and so forth" (p. 66). 
Jones (2004) believes that an examination of teacher attitudes and beliefs should take place throughout teacher education programs to point out their effects on practice. Yost, Forlenza - Bailey, and Shaw (1999) focus their research on belief structures and state that "by acknowledging prior experiences and attitudes toward education, teacher educators can encourage pre-service teachers to reflect and analyze critically alternative paradigms" (p. 2). They found that diverse field experiences and reflective practices throughout the program changed initial attitudes and beliefs citing that "exposing pre-service teachers to experiences that enlighten them about diverse populations will help them not only deal more effectively with diversity but learn how to capitalize on these elements to benefit all learners" (p. 12).

\section{Implications for Policy and Practice}

This study has implications for both policy and practice within teacher education programs. First, it informs teacher education programs as to what is needed to produce graduates who are prepared to teach in today's diverse classroom settings. The data revealed that clinical experience, although intensive and varied in some respects is not always sufficient enough to prepare pre-service students in special education to teach in today's diverse classrooms. Findings suggest that teacher education programs with students gaining an endorsement in special education should require more variation in the clinical experiences they provide for these students regarding student diversity characteristics. This variance should occur in the exposure to placements that offer students from differing racial and economical backgrounds as well as students with differing levels of special needs. 
The second implication is that these programs should provide course content that provides a focus on how to work with diverse student populations, not just diversity in terms of disability. Data revealed that participants felt that they were unwilling to teach in specific settings based upon the skill set that they gained from their teacher education program. In other words, had they received specific strategies within their coursework to put into practice during their clinical experience, they may feel better suited to teach students from diverse backgrounds.

Lastly, teacher education program policy can be informed by the results of this study. The data revealed that more informed, consistent, and streamlined methods of communication are needed within programs. Participants indicated that better communication between faculty to students, faculty to faculty, and general education and special education departments would have helped ensure that required concepts were not only evident and mastered but that any level of uncertainties in the quality of the preparation program would be eliminated.

\section{Limitations}

This study had several limitations. First and foremost, the study participants lacked any racial diversity. Even though the demographics of study participants were somewhat varied as far as where they were from, the 18 participants represented five different states, (see Chapter 3 pp. 38-39 for participant demographics), for the most part they lacked variance in other areas. This population sample is somewhat representative of a typical graduate of today's teacher education program; the entire population was $100 \%$ white, $100 \%$ from suburban areas, and the background characteristics were rather similar. Many comments were made regarding the similarity 
between experiences where they grew up and those experienced during their clinical placements. Therefore, it should be noted that the results of this research study may not be generalizable to other individuals and programs.

Because the teaching scenarios were developed to be hypothetical and loosely based upon real school districts, the ability to generalize the results may be somewhat limited. Also, because the study was conducted based upon candidates at only one institution, it lacks comparison and it should be noted that the results may not be applicable to other institutions.

Perhaps the time at which the data were collected (end of the semester) affected the results. Many participants had already begun the process of securing an actual teaching position so were somewhat prepared on what they expected from an ideal position. Also, there were participants who had already interviewed for certain positions again affecting what their perspectives were on what they deemed ideal. Collection of data collection for this study at this particular point may have very well skewed the results and it should be noted that data collection at any other point in the program may have produced different results, thus making this a limitation of this particular study.

Lastly, researcher bias can affect the results of a study. As a female, an AfricanAmerican, and a special educator, the researcher holds beliefs about individuals from diverse backgrounds that may be different from those of study participants. An emphasis on diversity awareness and acceptance during various teaching activities at WVU by the researcher was well known and, thus, could have influenced the way in which participants responded to the scenarios. It is important to note that study participants' first special education course was taught by the researcher and discussion 
regarding this fact occurred during several interview sessions. Participants noted the positive experience and how if not for that experience, they may not have continued in the program. One reflected upon her experiences in the program regarding all that she learned with, "I remember when we had you in class you always talked about the kid that would always scratch your hands." She went on to explain the importance of understanding what is learned in the program and specified "I think it is just getting to know your students and getting to know what works for them." Two participants discussed not only the positive experience of having the researcher in class but having another faculty member. When asked about strengths of the program, participant (Cranberry) responded,

...on the special ed side and I can speak for most in the program, we have never had a good teacher. We always say you were our first one and you were our last one for seven years...it was the coursework and the lack of passion. Dr. Xxxxx (African-American faculty member) was good too.

Another participant, who was one of very few to categorize her home city as urban, stated,

Let's start with your class [it] was really the start of thinking about and I don't care what I say, I am white, everybody isn't going to be. There are differences as far as racially and how to do that....So I think your class is the first class that opened my eyes to that. Then I had Dr. Xxxxx (African-American faculty member) for one of the differentiated instruction classes and that was really helpful. We never really had any other classes that have really helped us do anything. 
These comments show that this situation could have affected the results and thus, rendering them inapplicable to other participants and/or other institutions.

\section{Recommendations for Future Research}

The analysis conducted during this study presented a number of recommendations for future research in the area of teacher education training. It is hoped that the following will be beneficial in providing guidance to assist in the development and implementation of strategies that will enhance teacher education nationally:

1. Because of limited amount of research available pertaining to this phenomena and the limitations outlined in this study, the researcher feels that replicating the study and making it a longitudinal one where participants are followed through their first year after graduation would provide more insight into the types of teaching positions actually selected and how they compare to what is listed in the initial phase of data collection as an ideal placement.

a. This recommendation would allow for an examination into whether study participants' perceptions changed and how.

2. This study should be replicated at similar institutions across the nation. Since this particular study did not include any racially diverse participants, a recommendation is that a comparison study with pre-service students enrolled in an institution located in an urban area and in urban placements should be conducted to determine if differences exist between the choices of ideal teaching positions and the beliefs/perceptions pertaining to those choices. 
3. To further understand the influence of clinical experience on perceptions, a pre and post study to be conducted at the beginning and again at the end of the internship year is recommended. Future studies of this nature would provide insight and thus be able to determine if clinical experiences affect pre-service students.

4. Results of this study indicated a need for more streamlined coursework and increased communication within both the general education and special education programs. In order to best prepared candidates for today's classrooms, programs should examine this phenomena and include coursework that is relative, includes specific teaching strategies, and lacks redundancy across courses.

5. Study findings revealed that pre-service students in special education did not feel as well prepared for today's diverse classrooms as they felt they could have been. It is recommended that a more in-depth look at clinical placements occur to ensure that the most diverse experiences possible can be gained by teachers prior to entering the teaching field. 


\section{Appendix A}

Dear Student,

This letter is a request for you to take part in a research project to determine factors that influence choices of teaching positions by pre-service students in special education at WVU. You have been asked to participate in this research study as partial fulfillment of requirements for a doctoral degree in the Department of Special Education at West Virginia University. This project is being conducted by Tara Brooks, MA, under the direction of Dr. Barbara Ludlow, Professor and Chair, and principal investigator of this study. Your participation in this study is greatly appreciated and will be conducted in two sessions, with the first session requiring approximately 10 minutes to complete the attached scenarios and approximately 30 minutes for a follow-up interview session.

Any information about you obtained as a result of your participation in this research will be kept as confidential as legally possible. In any publications or presentations that result from this research, neither your name nor any information from which you might be identified will be used without your consent. Your participation in this research study is completely voluntary and you may discontinue at any time. Your refusal to participate or withdraw will not affect your class standing. Please note that you do not have to answer all of the questions during the interview session. West Virginia University's Institutional Review Board acknowledgment of this project is on file.

I hope that you will participate in this research project, as it could be beneficial in determining the factors that affect choices of teaching positions by pre-service students in special education. If you would like to see the interview questions prior to signing the consent form, a copy will be made available to you.

If you have any questions or concerns related to this research project, please feel free to contact me at tara.brooks@mail.wvu.edu or 304.293.4555 x3502. Contact information for Dr. Ludlow is as follows: Barbara.ludlow@mail.wvu.edu or 304.293-3450 $\mathrm{x} 1127$.

Thank you for your time and help with this project.

Sincerely,

Tara A. Brooks 


\title{
CONSENT AND INFORMATION FORM
}

\author{
Principal Investigator: Ludlow, Barbara \\ Department: \\ WVU HR\&E - Special Education \\ Tracking Number:
}

\section{Study Title:}

Factors Influencing the Choice of Teaching Positions by Pre-service Students in Special Education

\section{Co-Investigator(s):}

Brooks, Tara

\section{Contact Persons}

In the event you questions related to this research, you should contact Tara Brooks at (304) 293-4555. For more information about this research and about research-related risks, you can contact Dr. Barbara Ludlow at (304) $293-3450 \times 1127$.

Please contact the Office of Research Compliance at (304) 293-7073 for any of the following:

1. for problems or concerns about this research study;

2. for information regarding your rights as a research subject;

3. suggestions or questions about research in general.

\section{Introduction}

You have been asked to participate in this research study, which has been explained to you by Tara A. Brooks, M.A. This study is being conducted by Tara Brooks in the Department of Special Education at West Virginia University.

\section{Purposes of the Study}

The purpose of this study is to obtain scientifically valid and useful data for the enhancement of teacher education programs at WVU and across the nation. Your participation in this study is requested because of your commitment to special education as evidenced by your quest for added certification upon your degree to be obtained in May 2010. I expect to enroll approximately 18 subjects for participation in this study.

\section{Description of Procedures}

This study involves hypothetical teaching positions developed to determine if characteristics of student diversity affect position selection. Each participant will be asked to rank the teaching positions from most ideal to least ideal. During this step, the participant will also document any thoughts or questions relative to each scenario as they complete their rankings. You will be asked to provide contact information that will be used to schedule interview sessions in which I will present a series of follow-up questions related to the mock teaching positions as well as participants' preferences in general when selecting an ideal teaching position. You do not have to answer all the questions. You will have the opportunity to see the questions before signing this consent form. An interview schedule will be set up over the course of two weeks. If needed, participants may be contacted for follow-up interviews.

The actual interview will consist of about a 30-45 minute session and, with your permission, will be audio-taped for later transcription. A transcriber will be hired and $\mathrm{s} /$ he will only be able to identify each participant by participant1, participant2, etc. The tapes will be kept safe at the researcher's house in a locked box and no one else will have access to the 
tapes. Once all tapes are transcribed, a master tape will be made and the originals will all be destroyed. The master tape will be maintained for records and kept in a safe place in the researcher's home.

\section{Risks and Discomforts}

Although there is no major risk associated with participation in this study, the possibility of discomfort associated with answering interview questions exists. I expect minimal harm as a result of your participation.

\section{Alternatives}

You do not have to participate in this study.

\section{Benefits}

Possible benefits that may result from your participation include the improvement of the fiveyear teacher education program at WVU. The knowledge gained from this study may eventually benefit others.

\section{Confidentiality}

Any information that is obtained as a result of your participation in this research will be kept as confidential as legally possible. Audiotapes will be kept locked up and will be destroyed as soon as possible after the research is finished and a master tape is made.

In any publications that result from this research, neither your name nor any information from which you might be identified will be published without your consent.

You may cancel this authorization at any time by writing to the Principal Investigator: Barbara Ludlow, Ed.D.

509E Allen Hall

PO Box 6122

Morgantown, WV 26506-6122

This authorization will not expire unless you cancel it.

\section{SIGNATURE}

I have read this section and all of my questions have been answered. By signing below, I acknowledge that I have read and accept all of the above.

Signature of Subject or Authorized Representative

\section{Date}

Print Name of Subject or Authorized Representative

\section{Voluntary Participation}

Refusal to participate or withdrawal will not affect your class standing and will involve no penalty to you.

\section{Interview Protocol}




\section{Five-Year Program Students}

1. Demographic information:

Initials:

Gender:

Age:

1. In what city/state were you raised?

2. Would you characterize where you grew up as rural, urban, suburban, or other? If other, please explain.

3. In what social class would you categorize your family when you were growing up- lower, middle, or upper?

4. What factor(s) affected your decision to go into education?

5. What factors affected your decision to get an additional endorsement in special education?

II. Contact Information:

Phone number:

E-mail address: 


\section{Scenarios}

Considering all information not otherwise noted is identical, please review the following hypothetical schools and rank them in order from one in which you would be MOST (6) apt to accept a teaching position to one that you would be LEAST (1) likely to accept a position if offered. As you examine the scenarios, record your initial thoughts/reactions on each scenario in the space provided, including the factors most important to you in each.

\section{Chestnut Grove Elementary:}

Seeking qualified applicants for the position of Special Education Teacher.

Applicants must be energetic, have good communication skills and hold certification in at least one state. The Chestnut Grove School District is an urban school district serving the upper-middle class population with the racial make-up of students being predominately White and Black. It is one of the area's topperforming schools with the majority of students identified being included in the general education classrooms for the majority of the day. The percentage of students receiving free/reduced lunch is $30 \%$. The starting salary is $\$ 40,000$. Recent graduates are welcome to apply.

\section{Keystone Elementary:}

Seeking qualified applicants for the position of Special Education Teacher. Applicants must be energetic, have good communication skills and hold certification in at least one state. The Keystone School District is located in a wealthy suburban area and the majority population is White with fewer than $10 \%$ receiving free/reduced lunch. Of the total student population, $14 \%$ have been identified as having special needs however the district is on the lower end of the 
performance scale based upon last year's test results. The starting salary is $\$ 39,000$. Recent graduates are welcome to apply.

\section{Destiny Elementary:}

Seeking qualified applicants for the position of Special Education Teacher. Applicants must be energetic, have good communication skills and hold certification in at least one state. The Destiny School District is considered a rural, low socio-economic status area and serves a very racially diverse student population. There is a high percentage of students receiving free/reduced lunch $(79 \%)$ as well as a $36 \%$ of students identified as needing special education services. The district barely met AYP last year but has already instituted new policies to ensure it does so next year. The starting salary is $\$ 48,690$. Recent graduates are welcome to apply.

\section{Amherst Peace Elementary:}

Seeking qualified applicants for the position of Special Education Teacher. Applicants must be energetic, have good communication skills and hold certification in at least one state. The Amherst School District is located in a high socio-economic suburban area and is listed as one of the top schools in the metropolitan area. The student population is predominately White, and $18 \%$ are receiving free/reduced lunch. Percentage of students receiving special education 
services is about $38 \%$. The starting salary is $\$ 46,678$. Recent graduates are welcome to apply.

\section{Milvale Elementary}

Seeking qualified applicants for the position of Special Education Teacher. Applicants must be energetic, have good communication skills and hold certification in at least one state. The Milvale School District is an inner-city school district located in a working class area. This area is considered to be one of the most racially and culturally diverse areas of the city and did not meet AYP last year. The percentage of those identified as having special needs is $20 \%$ and receiving free/reduced lunch is $40 \%$. This position has a starting salary of $\$ 50,585$. Recent graduates are welcome to apply.

\section{South Park Elementary}

Seeking qualified applicants for the position of Special Education Teacher. Applicants must be energetic, have good communication skills and hold certification in at least one state. The South Park School District is located in a rural area and is one of few schools in the district meeting AYP last year. The majority of the students served come from families of low socio-economic status of White, Black, and Hispanic decent. The district operates under a full inclusion model and applicants would be required to have a foundational understanding of 
differentiated instruction and Response to Intervention. The starting salary is $\$ 40,980$. Recent graduates are welcome to apply.

\section{Probing questions}

1. Why did you rank School $(X) \# 1$ ? School $(Y) \# 2$ ? School (Z) \#6?

2. Can you describe for me the most important factor considered in ranking each hypothetical teaching position?

3. What are the characteristics that you used in ranking the scenarios?

4. What about certain scenarios led you to avoid them when looking for your top choices?

5. What other factors did you consider in your rankings? Why?

6. How did you consider the student diversity characteristic of race in your rankings? Class? Disability?

\section{Follow-up questions}

1. Tell me why you choose to go into teaching.

2. Talk to me about your decision to add the specialization to your education degree.

3. Describe for me your "ideal" teaching position.

4. To what degree has your "ideal" changed or stayed the same as a result of your experiences in the 5 year program? Explain. 
5. Can you describe any experiences in your credentialed program that you believe well prepared you for teaching in today's classrooms? How about any that did not prepare you for this role?

6. What is the single most important factor that you consider in selecting a teaching position?

7. Are there any other relevant factors that may affect your consideration of a teaching position?

8. What are some of the strengths of the teacher education program in preparing you to be a likely candidate for any available teaching position upon graduation?

9. What are some of the weaknesses?

10. Do you have any suggestions for improving the program to better prepare graduates to enter the teaching field upon graduation? 


\section{Appendix B}

Why go into teaching? SPED??

\begin{tabular}{|c|c|c|c|c|}
\hline $\begin{array}{l}\text { Participant } \\
\& \\
\text { Gender }\end{array}$ & Hometown & $\begin{array}{l}\text { Factors affecting } \\
\text { decision to go into } \\
\text { teaching }\end{array}$ & To add SpEd certification & $\begin{array}{l}\text { Interview data on } \\
\text { same questions }\end{array}$ \\
\hline 19. $\mathrm{F}$ & Cameron & $\begin{array}{l}\text { Great teachers and } \\
\text { Special Olympics }\end{array}$ & $\begin{array}{l}\text { Special Olympics and working } \\
\text { with special needs students }\end{array}$ & $\begin{array}{l}\text { Have always wanted to; } \\
\text { special Olympics; never } \\
\text { thought of anything other } \\
\text { than SPED }\end{array}$ \\
\hline 20. F & Morgantown & $\begin{array}{l}\text { Always wanted to } \\
\text { work with kids and } \\
\text { teach them }\end{array}$ & Very rewarding & $\begin{array}{l}\text { Always wanted to; } \\
\text { volunteered in sped room; } \\
\text { family members with diff } \\
\text { disabilities; experience @ } \\
\text { REM ->autism }\end{array}$ \\
\hline 21. $\mathrm{M}$ & Pittsburgh, $\mathrm{Pa}$ & $\begin{array}{l}\text { Family, former } \\
\text { teachers }\end{array}$ & Family, personal interest & $\begin{array}{l}\text { Influences growing up; } \\
\text { family (brother with IEP) }\end{array}$ \\
\hline 22. $\mathrm{M}$ & Pittsburgh, $\mathrm{Pa}$ & $\begin{array}{l}\text { Parents, passion, } \\
\text { needs }\end{array}$ & Job opportunity and passion & $\begin{array}{l}\text { Like working with children; } \\
\text { passion }\end{array}$ \\
\hline 23. $\mathrm{F}$ & Pittsburgh, $\mathrm{Pa}$ & Personal choice & $\begin{array}{l}\text { Personal preference }- \text { feel can } \\
\text { help more }\end{array}$ & $\begin{array}{l}\text { Hated school; family } \\
\text { influence }\end{array}$ \\
\hline 24. $\mathrm{F}$ & Rural Pa & Job shadowing & $\begin{array}{l}\text { Wanted to be a better teacher in } \\
\text { general ed }\end{array}$ & Shadowing; better teacher \\
\hline 25. $\mathrm{F}$ & $\begin{array}{l}\text { Baltimore, } \\
\text { MD }\end{array}$ & Love for children & $\begin{array}{l}\text { Experience babysitting CP, } \\
\text { grandfather MMI }\end{array}$ & $\begin{array}{l}\text { Loved kids; babysitting and } \\
\text { grandfather }\end{array}$ \\
\hline 26. $\mathrm{F}$ & $\begin{array}{c}\text { Williamsville } \\
, \mathrm{NY}\end{array}$ & $\begin{array}{l}\text { Parents, friends, high } \\
\text { school }\end{array}$ & & $\begin{array}{l}\text { Loved school; parental } \\
\text { influence; experiences }\end{array}$ \\
\hline 27. $\mathrm{F}$ & Bridgeport & $\begin{array}{l}\text { Passion for the } \\
\text { profession }\end{array}$ & $\begin{array}{l}\text { Neighbor who is autistic - big } \\
\text { influence }\end{array}$ & $\begin{array}{l}\text { Always been a passion; } \\
\text { neighbor }\end{array}$ \\
\hline 28. F & Parkersburg & $\begin{array}{l}\text { High school } \\
\text { experience, freedom } \\
\text { writers }\end{array}$ & Family and work experience & $\begin{array}{l}\text { Freedom Writers movie; } \\
\text { work in daycare }\end{array}$ \\
\hline 29. $\mathrm{M}$ & Parkersburg & Family & family & $\begin{array}{l}\text { Family influence; just kind } \\
\text { of picked it - was thrown @ } \\
\text { him }\end{array}$ \\
\hline $30 . \quad F$ & Parkersburg & $\begin{array}{l}\text { Want to make a } \\
\text { difference }\end{array}$ & Brother - Downs & Little brother \\
\hline 31. $\mathrm{F}$ & Wellsburg & Parents encouraged & $\begin{array}{l}\text { Mom works with students } \\
\text { w/special needs }\end{array}$ & $\begin{array}{l}\text { Always wanted to - love } \\
\text { kids; mom's work }\end{array}$ \\
\hline 32. $\mathrm{F}$ & Huntington & $\begin{array}{l}\text { Love for children } \\
\text { desire to make } \\
\text { change }\end{array}$ & $\begin{array}{l}\text { Opportunities to work with } \\
\text { students with special needs in } \\
\text { high school; family members }\end{array}$ & $\begin{array}{l}\text { Work in daycare; family } \\
\text { members }\end{array}$ \\
\hline 33. $\mathrm{F}$ & Charleston & $\begin{array}{l}\text { Past teachers } \\
\text { influence }\end{array}$ & $\begin{array}{l}\text { Passion for and working with } \\
\text { students w/ special needs }\end{array}$ & $\begin{array}{l}\text { Always wanted to be a } \\
\text { teacher; high school } \\
\text { coursework in psych -> sped }\end{array}$ \\
\hline 34. $\mathrm{F}$ & $\begin{array}{c}\text { Cranberry } \\
\text { Township, } \mathrm{Pa}\end{array}$ & Parents and self & $\begin{array}{l}\text { Perks, belief in self and wanted } \\
\text { to work with students } \\
\text { w/disabilities }\end{array}$ & $\begin{array}{l}\text { Always wanted to be a } \\
\text { teacher; mom encouraged } \\
\text { sped }\end{array}$ \\
\hline 35. $\mathrm{F}$ & Sterling, Va & $4^{\text {th }}$ grade teacher & Long term sub as sped assistant & $\begin{array}{l}\text { Had great } 4^{\text {th }} \text { grade teacher; } \\
\text { subbing }\end{array}$ \\
\hline 36. $\mathrm{F}$ & $\begin{array}{c}\text { Elkins/ } \\
\text { Bel Air, MD }\end{array}$ & $\begin{array}{l}\text { Love for learning; } \\
\text { logical next step }\end{array}$ & $\begin{array}{l}\text { Past school experience helping } \\
\text { other students and sister }\end{array}$ & $\begin{array}{l}\text { Personal experiences in } \\
\text { sped; sister; experience }\end{array}$ \\
\hline
\end{tabular}




\section{References}

Alastuey, L., Justice, M., Weeks, S., \& Hardy, J. (2005, Fall). Why we complete a teacher education program - credentialed teachers: A critical incident inquiry. Education, 126(1), 37-46.

American Association for Employment in Education (AAEE). (2007). 2007 Executive summary: Educator supply and demand in the United States. Retrieved July 23, 2009 from http://aaee.org/cwt/external/wcpages/resource/.

Amrein-Beardsley, A. (2007, September). Recruiting expert teachers into hard-to-staff schools. Phi Delta Kappan, 64-67.

Anderson, B.A., Silver, B.D., \& Abramson, P.R. (1988b). The effects of the race of the interviewer on race-related attitudes of black respondents in SRC/CPS national election studies. Public Opinion Quarterly, 52(3), 289-324.

Andrews, L., Miller, N., Evans, S., \& Smith, S.D. (2003). An internship model to recruit, train, and retain special educators for culturally diverse urban classrooms: A program description. Teacher Education and Special Education, 26(1), 74-78.

Artiles, A.J. Rueda, R., Salazar, J.J., \& Higareda, I. (2005). Within-group diversity in minority disproportionate representation: English language learners in urban school districts. Exceptional Children, 71(3), 283-300.

Athanases, S.Z., \& Martin, K.J. (2006). Learning to advocate for educational equity in a teacher credential program. Teaching \& Teacher Education, 22(6), 627-646.

Barnes, C.J. (2006,Spring/Summer). Preparing preservice teachers to teach in a culturally responsive way. The Negro Educational Review, 57(1-2), 85-100.

Billingsley, B., Carlson, E., \& Klein, S. (2004). The working conditions and induction support of early career special educators. Exceptional Children, 70(3), 333-347.

Boe, E.E., Cook, L.H., \& Sunderland, R.J. (2008). Teacher turnover: Examining exit attrition, teaching area transfer, and school migration. Exceptional Children, 75(1), 7-31.

Boeije, H. (2002). A purposeful approach to the constant comparative method in the analysis of qualitative interviews. Quality \& Quantity, 36, 391-409.

Bogdan, R.C., \& Biklen, S.K. (2007). Qualitative research for education: An introduction to the theories and methods ( $5^{\text {th }}$ ed.). Boston: Pearson.

Borgemenke, A. J. (2001). Placement of minority and low socio-economic status 
students in special education self-contained settings. ETD Collection for University of Texas, El Paso. Paper AAI3035095. Retrieved August 3, 2009 from http://digitalcommons.utep.edu/dissertations/AAl3035095/.

Boyd, B.F. (1996, Spring). Issues of diversity in teacher education-pt1. Childhood Education, 72(3), [ACEl Exchange], 160-L.

Boyd, B.F. (1996, Summer). Issues of diversity in teacher education-pt2. Childhood Education, 72(3), [ACEI Exchange], 160-L.

Blanchett, W.J. (2006). Disproportionate respresentation of African American students in special education: Acknowledging the role of white privilege and racism. Educational Researcher, 35(6), 24-28.

Brown v. Board of Education of Topeka, 347 U.S. 483, (74S.Ct 686, 98 L. Ed. 873 1954).

Brown, K.M. (2004). Assessing preservice leaders' beliefs, attitudes, and values regarding issues of diversity, social justice, and equity: A review of existing measures. Equity \& Excellence in Education, 37, 332-342.

Brown, M.R. (2007). Educating all students: Creating culturally responsive teachers, classrooms, and schools. Intervention in School and Clinic, 43(1), 57-62.

Brownell, M.T. (2005). The center on personnel studies in special education: Research issues in teacher education. The Journal of Special Education, 38(4), 241.

Brownell, M.T., Bishop, A.M., \& Sindelar, P.T. (2005). NCLB and the demand for highly qualified teachers: Challenges and solutions for rural schools. Rural Special Education Quarterly, 24(1), 9-15.

Brownell, M.T., Hirsch, E., \& Seo, S. (2004). Meeting the demand for highly qualified special education teachers during severe shortages: What should policymakers consider? The Journal of Special Education, 38(1), 56-61.

Brownell, M.T., Ross, D.D., Colon, E.P., \& McCallum, C.L. (2005). Critical features of special education teacher preparation: A comparison with general teacher education. The Journal of Special Education, 38(4), 242-252.

Brownell, M.T., Smith, S.W., McNellis, J., \& Lenk, L. (1995). Career decisions in special education: Current and former teachers' personal views. Exceptionality, 5(2), 83- 102.

Burke, L.A., \& Miller, M.K. (2001, May). Phone interviewing as a means of data 
collection: Lessons learned and practical recommendations [30 paragraphs]. Forum Qualitative Sozialforschung/Forum: Qualitative Social Research [On-line Journal], 2(2). Retrieved online April 29, 2008 from http://qualitative-research.net/fqs/fqs-eng.htm.

Burnard, P. (1994, Feb). The telephone interview as a data collection method. Nurse Education Today, 14(1), 67-72.

Campbell, B. (1981). Race of interviewer effects among southern adolescents. Public Opinion Quarterly, 45, 231-234.

Cannella, G.S., \& Reiff, J.C. (1994). Teacher preparation for diversity. Equity \& Excellence in Education, 27(3), 28-33.

Carr, S.C., \& Evans, E.D. (2006). Helping beginning teachers remain in the profession: A successful induction program. Teacher Education and Special Education, 29(2), 113-115.

Chapman, D.W. (1984). Teacher retention: The test of a model. American Educational Research Journal, 21(3), 645-658.

Chism, M.M. (2009). Featured article: The role of an SEA in closing achievement gaps. Retrieved May 5, 2009 from http://www.learningpt.org/greatlakeswest/newsletters/featured roleofSEA.pdf.

Christie, K. (2009, April). States confront the deepest pockets of poverty. Phi Delta Kappan, 541-543.

Cochran-Smith, M. (1995, Fall). Color blindness and basket making are not the answers: Confronting dilemnas of race, culture, and language diversity in teacher education. American Educational Research Journal, 32(3), 493-522.

Coffey, K.M., \& Obringer, S.J. (2000). Culturally diverse rural students: At special risk for Id classification. Rural Special Education Quarterly, 19(2), 15-19.

Connor, D.J. (2006). Michael's story: "I get into so much trouble just by walking": Narrative knowing and life at the intersections of learning disability, race, and class. Equity \& Excellence in Education, 39, 154-165.

Cook, L.H., \& Boe, E.E. (2007). National trends in the sources of supply of teachers in special and general education. Teacher Education and Special Education, 30(4), 217-232.

Cotter, P.R., Cohen, J., \& Coulter, P.B. (1982). Race of interviewer effects in telephone interviews. Public Opinion Quarterly, 46, 278-284. 
Council for Exceptional Children (2008). Retrieved March 26, 2011 from http://www.cec.sped.org/content/navigationmenu/aboutcec/diversity/definitionofdi versity/default.htm.

Courtade, G.R., Servilio, K., Ludlow, B.L., \& Anderson, K. (2010). Highly qualified teacher requirements for special educators: Perceptions of West Virginia stakeholders. Rural Special Education Quarterly, 29(3), 37-49.

Coutinho, M.J., \& Oswald, D.P. (2004). Disproportionate representation of culturally and linguistically diverse students in special education: Measuring the problem. National Center for Culturally Responsive Educational SystemsRetrieved September 12, 2006 from www.nccrest.org.

Creswell, J.W. (2003). Research design: Qualitative, quantitative, and mixed methods approaches $\left(2^{\text {nd }}\right.$ ed.). Thousand Oaks, CA: Sage.

Darling-Hammond, L. (1999). America's future: Educating teachers. Education Digest, 64(9), 18-23.

Darling-Hammond, L. (2000). New standards and old inequalities: School reform and the education of African American students. Journal of Negro Education, 69(4), 263-287.

Darling-Hammond, L. (2001, May). The challenge of staffing our schools. Educational Leadership 58(8), 12-17.

Darling-Hammond, L., \& Berry, B. (1999). Recruiting teachers for the $21^{\text {st }}$ century: The foundation for educational equity. Journal of Negro Education, 68(3), 254-279.

Davis, D.W. (1997). The direction of race and interviewer effects among AfricanAmericans: Donning the black mask. American Journal of Political Science, 41(1), 309-322.

Davis, D.W.,\& Silver, B.D. (2003). Stereotype threat and race of interviewer effects in a survey on political knowledge. American Journal of Political Science, 47(1), 3345.

Delpit, L. (1995). Other people's children: Cultural conflict in the classroom. New York: New Press.

Delpit, L., \& Dowdy, J.K. (Eds.). (2002). The skin that we speak: Thoughts on language and culture in the classroom. New York: New Press.

De Valenzuela, J. S., Copeland, S.R., Qi, C.H., \& Park, M. (2006). Examining educational equity: Revisiting the disproportionate respresentation of minority students in special education. Exceptional Children, 72(4), 425-441. 
Dewitt, D. (1994, Winter). Thinking about diversity. National Forum, 74(1), 16-18.

Dictionary.com. (2009). Retrieved 7-20-09 from http://dictionary.reference.com/browse/socioeconomic+status.

DiMartino, E.C. (1991). Teacher education for the $21^{\text {st }}$ century. Education, 111(3), 377381.

Dohrenwend, B.S., Colombotos, J., \& Dohrenwend, B.P. (1968)Social distance and interviewer effects. Public Opinion Quarterly, 32, 410-422.

Dowling, K. A., Magrou, J., Broo, K. , McFalls, T. and Randolph, N. , 2008-10-15 "Multicultural Experiences in the Field: Pre-Service Teacher Perspectives" Paper presented at the annual meeting of the MWERA Annual Meeting, Westin Great Southern Hotel, Columbus, Ohio Online <PDF>. 2009-05-23 from http://www.allacademic.com/meta/p275483_index.html

Edwards, R. (2004, November/December). Ethnicity and disability. TASH Connections, 3-4.

Ferri, B.A., \& Connor, D. J. (2005). Tools of exclusion: Race, disability, and (re)segregated education. Teachers College Record, 107(3), 453-474.

Finkel, S.E., Guterbock, T.M., \& Borg, M.J. (1999). Race of interviewer effects in a preelection poll: Virginia 1989. Public Opinion Quarterly, 55(3), 313-330.

Ford, A., Pugach, M.C., \& Otis-Wilborn, A. (2001). Preparing general educators to work well with students who have disabilities: What's reasonable at the preservice level? Learning Disability Quarterly, 24, 275-285.

Freebody, P. (2003). Qualitative research in education: Interaction and practice. Thousand Oaks, CA: Sage.

Friedman, L., \& Friedman, H.H. (1978). Does the perceived race of a telephone interviewer affect the responses of white subjects to an attitude toward negroes scale. Retrieved 4/28/08 from http://www.amstat.org/Sections/Srms/Proceedings/papers/1978 115.pdf.

Gallegos, A., \& McCarty, L.L. (2000). Bilingual multicultural special education: An integrated personnel preparation program. Teacher Education Special Education, 23(4), 264-270.

Gay,G. (2000). Culturally responsive teaching: Theory, research, and practice. New York: Teacher's College Press. 
Gay, G. (1997). Multicultural infusion in teacher education: Foundations and applications. Peabody Journal of Education, 72(1), 150-177.

Gehrke, R. S., \& McCoy, K. (2007). Considering the context: Differences between the environments of beginning special educators who stay and those who leave. Rural Special Education Quarterly, 26(3), 32-40.

Gehrke, R.S., \& Murri, N. (2006). Beginning special educators' intent to stay in special education: Why they like it here. Teacher Education and Special Education, 29(3), 179-190.

Georgia Department of Education. Retrieved April 26, 2008 from http://www.doe.k12.ga.us/.

Green, S.L. (2007, Summer). Preparing special educators to work with diverse student populations: Culturally responsive teaching and its alignment with the teaching of social studies. Black History Bulletin, 70(1). 12-18.

Grossman, H. (1995). Special education in a diverse society. Needham Heights, MA: Allyn and Bacon.

Harms, B.M., \& Knobloch, N.A. (2005). Preservice teachers' motivation and leadership behaviors related to career choice. Career and Technical Education Research, 30(2), 101-124.

Harrison County Board of Education. Retrieved April 26, 2008 from http://www.harcoboe.com/.

Harry, B., Sturges, K.M., \& Klinger, J.K. (2005). Mapping the process: An exemplar of process and challenge in grounded theory analysis. Educational Researcher, 34(2), 3-13.

Hatch, J.A. (2002). Doing qualitative research in education settings. Albany, NY: State University of New York Press.

Hatchett, S., \& Schuman, H. (1975-1976). White respondents and race of interviewer effects. Public Opinion Quarterly, 39, 523-528.

He, Y., \& Levin, B.B. (2008, Fall). Match or mismatch? How congruent are the beliefs of teacher candidates, cooperating teachers, and university-based teacher educators? Teacher Education Quarterly, 35(4), 37-55.

Heilman, E.E. (2004). Hoosiers, hicks, and hayseeds: The controversial place of marginalized ethnic whites in multicultural education. Equity \& Excellence in Education, 37, 67-79. 
Hellman, D. (2008). Do music education majors intent to teach music: An exploratory survey. Update: Applications of Research in Music Education, 27(1), 65-70.

Hewitt-Taylor, J. (2001). Use of constant comparative analysis in qualitative research. Nursing Standard, 15(42), 39-42.

Hill, H. (1997, 7/11). The importance of a minority perspective in the classroom. Chronicle of Higher Education, 44(11), A60.

Hodkinson, P., \& Sparkes, A.C. (1997). Careership: A sociological theory of career decision making. British Journal of Sociology of Education, 18(1). 29-44.

Holm, L., \& Horn, C. (2003). Priming schools of education for today's teachers. Phi Delta Kappan, 84, 376-380. Retrieved from www.edigest.com on September 10, 2006.

Horng, E. (2009). Teacher Tradeoffs: Disentangling Teachers' Preferences for Working Conditions and Student Demographics. American Educational Research Journal, 46(3), 690-717.

Howard, G.R. (1999). We can't teach what we don't know: White teachers, multiracial schools. New York: Teachers College Press.

Huddy, L., Billig, J., Bracciodieta, J., Hoeffler, L., Moynihan, P.J., \& Pugliani, P. (1997). The effect of interviewer gender on the survey response. Political Behavior, 19(3), 197-220.

Hyman, H., et al. (1954). Interviewing in Social Research. Chicago: University of Chicago Press.

Ingersoll, R.M. (2001, Fall). Teacher turnover and teacher shortages: An organizational analysis. American Educational Research Journal, 38(3), 499-534.

Janesick.V.J. (1998). Stretching exercises for qualitative researchers. Thousand Oaks, CA: Sage.

Johnson, E.S., Humphrey, M.J., \& Allred, K.W. (2009). Online learning and mentors: Addressing the shortage of rural special educators through technology and collaboration. Rural Special Education Quarterly, 28(2), 17-21.

Justice, M., \& Espinoza, S. (2007, Summer). Emotional intelligence and beginning teacher candidates. Education, 127(4), 456-461.

Kea, C.D., \& Utley, C.A. (1998). To teach me is to know me. The Journal of Special Education, 32(1), 44-47. 
Keogh, Barbara K. "Celebrating PL 94-142: the Education of All Handicapped Children Act of 1975. (Education of All Handicapped Children Act of 1975)." Issues in Teacher Education. 2007. Retrieved July 22, 2009 from accessmylibrary: http://www.accessmylibrary.com/article-1G1-173465145/celebrating-pl-94$\underline{142 . h t m l}$

Krysan, M. (1998). Privacy and the expression of white racial attitudes: A comparison across three contexts. Public Opinion Quarterly, 62, 506-644.

Ladson-Billings (1995). The dreamkeepers: Successful teachers of Black children. San Francisco: Jossey-Bass.

Laine, (2008). Teaching in changing times: A report from the national comprehensive center for teacher quality and public agenda. National Comprehensive Center for Teacher Quality. Retrieved July 23, 2008 from http://publicagenda.org/reports/lessons-learned-new-teachers-talk-about-theirjobs-challenges-and-long-range-plans-issue-no-1.

Larkin, J.M., \& Sleeter, C.E. (Ed.). (1995). Developing multicultural teacher education curricula. Albany, NY: State University of New York Press.

Leland, C.H., \& Harste, J.C.(2005). Doing what we want to become: Preparing new urban teachers. Urban Education, 40(1), 60-77.

Levin, B., \& He, Y. (2008). Investigating the content and sources of teacher candidates' personal practical theories (PPTs). Journal of Teacher Education, 59(1), 55-68.

Levine, A. (2006, November). Teacher education: Time to tame the wild west. Results from a new survey show teacher education programs are outdated and lackluster. Retrieved September 12, 2007 from www.districtadministration.com.

Manning, J.P., \& Gaudelli, W. (2006). What teacher educators should know about poverty and special education. Teacher Education and Special Education, 29(4), 236-243.

Mauser, A.J., \& Cranston-Gingras, A.M. (1988). Special education teacher certification trends: A national survey. (ERIC Document Reproduction Service No. ED348786).

McCleskey, J., Tyler, N.C., \& Flippin, S.S. (2003). The supply of and demand for special education teachers: A review of research regarding the chronic shortage of special education teachers. (COPSSE Document Number RS - 1E). Gainesville, FL: University of Florida, Center on Personnel Studies in Special Education.

McCleskey, J., Tyler, N.C., \& Flippin, S.S. (2004). The supply of and demand for 
special education teachers: A review of research regarding the chronic shortage of special education teachers. The Journal of Special Education, 38(1), 5-21.

McConnell, M.E., \& Townsend, B.L. (1997). How do you keep going? Intervention in School \& Clinic, 33(2), 125-127.

Melnick, S.L., \& Zeichner, K.M. (1998, Spring). Teacher education's responsibility to address diversity issues: Enhancing Institutional Capacity. Theory into Practice, 37(2), 88-95.

Menter, I. (1989). Teaching practice stasis: Racism, sexism, and school experience in initial teacher education. British Journal of Sociology of Education, 10(4), 459473.

Merriam, S.B. (1998). Qualitative research and case study applications in education. San Francisco, CA: John Wiley \& Sons, Inc.

Merriam, S.B. and associates (2002). Qualitative research in practice: Examples for discussion and analysis. San Francisco, CA: Jossey-Bass.

Miller, G., \& Dingwall, R. (Ed.). (1997). Context and method in qualitative research. London: Sage.

Milner, H.R., Flowers, L.A., Moore, Jr., E., Moore, III., J.L., \& Flowers, T.A. (2003). Preservice teachers' awareness of multiculturalism and diversity. High School Journal. 87(1), 63-70.

Milner, H.R. (2006). Preservice teachers' learning about cultural and racial diversity: Implications for urban education. Urban Education, 41(4), 343-375.

Mish, F.C. (Ed.). (1998). Merriam-Webster's Collegiate Dictionary (10 $10^{\text {th }}$ ed.). Springfield, MA: Merriam-Webster, Incorporated.

Monongalia County Board of Education. Retrieved April 26, 2008 from http://boe.mono.k12.wv.us/.

Montgomery County Schools Board of Education. Retrieved April 26, 2008 from http://www.montgomeryschoolsmd.org/

National Center to Improve Recruitment and Retention of Qualified Personnel for Children with Disabilities (Personnel Improvement Center). Retrieved November 8, 2009 from http://www.personnelcenter.org.

National Coalition on Personnel Shortages in Special Education and Related Services. Retrieved November 8, 2009 from http://specialedpros.com. 
National Education Association (2003). Male Teacher Fact Sheet. Retrieved November 19, 2008 from http://www.nea.org/teachershortage/03malefactsheet.html.

Nieto, S. (2004). Affirming diversity: The sociopolitical context of multicultural education $\left(4^{\text {th }}\right.$ ed.). Boston: Pearson Education, Inc.

North Elementary School. Retrieved April 26, 2008 from http://boe.mono.k12.wv.us/nes/.

Nougaret, A.A., Scruggs, T.E., \& Mastropieri, M.A. (2005). Does teacher education produce better special education teachers? Exceptional Children, 71(3), 217-229.

Novick, G. (2008). Is there a bias against telephone interviews in qualitative research? Research in Nursing \& Health, [On-line Journal], 9999(9999), n/a. Retrieved online 4/29/08 from http://www3.interscience.wiley.com/journal/117888201/abstract?CRETRY=1\&SR ETRY=0.

Otis-Wilborn, A.,Winn, J., Griffin, C., \& Kilgore, K. (2005). Beginning special educators' forays into general education. Teacher Education and Special Education, 28(3/4), 143-152.

Park, J., Turnbull, A.P., \& Turnbull, III, H.R. (2002). Impacts of poverty on quality of life in families of children with disabilities. Exceptional Children, 68(2), 151-170.

Patton, M.Q. (2002). Qualitative research \& evaluation methods ( $3^{\text {rd }}$ ed.). Thousand Oaks, CA: Sage.

Pogrow, S. (2006, November). Restructuring high-poverty elementary schools for success: A description of the hi-perform school design. Phi Delta Kappan, 223229.

Pohan, C.A. (1996). Preservice teachers' beliefs about diversity: Uncovering factors leading to multicultural responsiveness. Equity \& Excellence in Education, 29(3), 62-67.

Rao, S. (2005, Winter). Effective multicultural teacher education program: Methodological and conceptual issues. Education, 126(2), 279-291.

Reid, D.K., \& Knight, M.G. (2006). Disability justifies exclusion of minority students: A critical history grounded in disability studies. Educational Researcher, 35(6), 1823.

Reynard, H.E. (1957). Beginning teachers select their schools. Educational Research Bulletin, 36(5), 183-187.

Robins, K.N., Lindsey, R.B., Lindsey, D.B., \& Terrell, R.D. (2006). Culturally proficient 
instruction: A guide for people who teach ( $2^{\text {nd }}$ ed.). Thousand Oaks, CA: Corwin Press.

Rosaen, C.L. (2003). Preparing teachers for diverse classrooms: Creating public and privates spaces to explore culture through poetry writing. Teachers College Record, 105(8), 1437-1485.

Rots, I., \& Aelterman, A. (2008) Two Profiles of Teacher Education Graduates: a discriminant analysis of teaching commitment, European Educational Research Journal, 7(4), 523-534. http://dx.doi.org/10.2304/eerj.2008.7.4.523

Rots, I., Aelterman, A.,Vlerick, P., \& Vermeulen, K. (2007). Teacher education, graduates' teaching commitment and entrance into the teaching profession. Teaching and Teacher Education, 23, 543-556.

Sapon-Shevin, M., \& Zollers, N.J. (1999). Multicultural and disability agendas in teacher education: Preparing teachers for diversity. International Journal of Leadership in Education, 2(3), 165-190.

Schroth, G., Pankake, A., Fullwood, H., \& Gates, G. (2001).Rural and urban American. Rural Special Education Quarterly, 20(1/2), 6-12.

Schuman, H., \& Converse, J.M. (1971). The effects of black and white interviewers on black responses in 1968. Public Opinion Quarterly, 35(1), 44-68.

Shealey, M.W. Lue, M.S., Brooks, M., \& McCray, E. (2005, March/April). Examining the legacy of Brown: The impact of special education and teacher practice. Remedial and Special Education, 26(2), 113-121.

Singer, E., Frankel, M.R., \& Glassman, M.B. (1983). The effect of interviewer characteristics and expectations on response. Public Opinion Quarterly, 47, 6883.

Skiba, R.J, Simmons, A.B., Ritter, S., Gibb, A.C., Rausch, M.K., Cuadrado, J., \& Chung, C. (2008). Achieving equity in special education: History, status, and current challenges. Exceptional Children, 74(3), 264-288.

Smith, D. D., Tyler, N.C., Easterling, J., Smith-Davis, J. Clarke, C.C., \& Mims, V.A. (2000). Technical assistance makes a difference: The alliance 2000 story. Teacher Education Special Education, 23(4), 303-310.

Snook, C. (2005, Jan). The effect of interviewer context on white respondents' answers to questions of racial policy and stereotypes. Paper presented at the annual meeting of the Southern Political Science Association, Inter-Continental Hotel, New Orleans, LA Online <.PDF> Retrieved April 12, 2008 from http://www.allacademic.com/meta/p67344 index.html. 
Solomon, R.P., Portelli, J.P., Daniel, B., \& Campbell, A. (2005). The discourse of denial: How white teacher candidates construct race, racism, and 'white privilege'. Race Ethnicity and Education, 8(2), 147-169.

Stake, R.E. (1995). The art of case study research. Thousand Oaks, CA: Sage.

Sturges, J.E., \& Hanrahan, K.J. (2004). Comparing telephone and face-to-face qualitative interviewing: A research note. Qualitative Research, 4, 107-118.

Sundeen, T.H., \& Wienke,W.D. (2009). A model for recruiting and preparing new rural special educators: Mining an untapped potential. Rural Special Education Quarterly, 28(1), 3-10.

Swartz, E. (2003). Teaching white preservice teachers: Pedagogy for change. Urban Education, 38(3), 255-278.

Sweet, L. (2002, Feb). Telephone interviewing: Is it compatible with interpretive phenomenological research? Contemporary Nurse, 12, 58-63.

The Council for Exceptional Children [CEC]. (1998). What every special educator must know: The international standards for the preparation and licensure of special educators. ( $3^{\text {rd }}$ ed.). Reston, VA: Author.

Thornton, B., Peltier, G. \& Medina, R. (2007). Reducing the special education teacher shortage. The Clearing House, 80(5), 233-238.

Townsend, B.L. (2002). Leave no teacher behind: A bold proposal for teacher education. Qualitative Studies in Education, 15(6), 727-738.

Trent, S.C., Kea, C.D., \& Oh, K. (2008). Preparing preservice educators for cultural diversity: How far have we come? Exceptional Children, 74(3), 328-350.

Tyler, N.C., Cantou-Clarke, C.D., Easterling, J., \& Klepper, T. (2003). Recruitment and retention and special education teacher preparation in rural areas: Diversity, federal funding, and technical assistance considerations. Rural Special Education Quarterly, 22(3), 3-11.

Tyler, N., \& Smith- Davis, D. (2000). Welcome to the TESE special issue: Preparation of culturally and linguistically diverse special educators. Teacher Education Special Education, 23(4), 261-263.

Tucker, C. (1983). Interviewer effects in telephone surveys. Public Opinion Quarterly, 47, 84-95.

U.S. Census Bureau. (2009). Small area income and poverty estimates (SAIPE) 
program. Retrieved August 1, 2009 from www.census.gov.

U.S. Department of Education, Office for Civil Rights, Achieving diversity: Race-neutral alternatives in American education, Washington, D.C., 2004.

U.S. Department of Education, Office of Special Education Programs (OSEP), (2009). Retrieved July 26, 2009 from http://www.ed.gov/about/offices/list/osers/reports.html.

U.S. Department of Education, Institute of Education Sciences, National Center for Education Statistics, Teacher Quality: A Report on the Preparation \& Qualifications of Public School Teachers. US Deparment of Education Auditorium: January 28, 1999. Retrieved May 5, 2009 online from http://nces.ed.gov.

U.S. Department of Education, Institute of Education Sciences, National Center for Education Statistics (2008). Digest of Education Statistics, 2007. Retrieved January 23, 2008 and May 8, 2008 online from http://nces.ed.gov.

U.S. Department of Education, Institute of Education Sciences, National Center for Education Statistics (2008). The Condition of Education. Retrieved May 6, 2009 online from http://nces.ed.gov.

U.S. Department of Labor, Bureau of Labor Statistics (2007). Occupational Outlook Handbook, 2008-09 Edition. Retrieved August 20, 2009 from http://www.bls.gov/OCO/ocos070.htm.

Utley, C.A., \& Obiakor, F.E. (1997). Addressing diversity in special education research. ERIC Digest. Retrieved August 3, 2009 from http://www.ericdigests.org/2202$\underline{4 / \text { diversity.html. }}$

Vaznis,J. (2008, November 18). Hunt is on for more men to lead classrooms. The Boston Globe. Retrieved January 16, 2008 from http://www.boston.com.

Villegas, A.N., \& Lucas, T. (2002). Preparing culturally responsive teachers: Rethinking the curriculum. Journal of Teacher Education, 53(20), 20-32.

Wallace, B.C. (2001). A call for change in multicultural training at graduate schools of education: Educating to end oppression for social justice. Teachers College Record, 102(6), 1086-1111.

Wasburn-Moses, L. (2009). An exploration of pre-service teachers' expectations for their future roles. Teacher Education and Special Education, 32(1), 5-16.

Wasley, P. (2008, May 21). New teachers say they are ill prepared for classroom 
diversity and special -needs students. The Chronicle of Higher Education. Retrieved March 8, 2011 from http://chronicle.com/article/New-Teachers-AreUnprepared/814

Watson, D. (2011). Urban, but not too urban: Unpacking teachers' desires to teach urban students. Journal of Teacher Education, 62(1), 23-34.

Weeks, M., \& Moore, P. (1981). Ethnicity of interviewer effects on ethnic respondent. Public Opinion Quarterly, 45, 245-249.

Weisman, E.M., \& Garza, S.A. (2002). Preservice teacher attitudes toward diversity: Can one class make a difference? Equity \& Excellence in Education, 35(1), 2834.

West Virginia Dept of Education. Retrieved April 22, 2008 from http://wvde.state.wv.us/

Wiersma W., \& Jurs, S.G. (2005). Research methods in education: An introduction ( $8^{\text {th }}$ ed.). Boston, MA: Pearson Education, Inc.

White, J. (1999). The impact of clinical experiences during preregistration diploma in nursing courses on initial career choice. Journal of Nursing Management, 7, 157165.

Wilson, D., \& Ludwig, J. Respondent views on perceived racial context and race of interviewer effects. Paper presented at the annual meeting of the American Association for Public Opinion Association, Fontainebleau Resort, Miami Beach, $F L<$ Not available $>2008-04-21$ from http://allacademic.com/meta/p15841 index.html.

Young, B.J. (1995). Career plans and work perceptions of preservice teachers. Teaching \& Teacher Education, 11(3), 281-292.

Yost, D.S, Forlenza-Bailey, A., \& Shaw, S.F. (1999). Teachers who embrace diversity: The role of reflection, discourse, and field experiences in teacher education. The Professional Educator, 21(1), 1-14. 